

\title{
Why do people continue to live near polluted sites? Empirical evidence from Southwestern Europe
}

\author{
Pierre Levasseur $^{1, *}$, Katrin Erdlenbruch ${ }^{1,2}$ and Christelle Gramaglia ${ }^{1}$ \\ ${ }^{1}$ G-EAU, Irstea, AgroParisTech, Cirad, IRD, Montpellier SupAgro, Univ Montpellier, Montpellier, France \\ ${ }^{2}$ Cee-M, Université de Montpellier, CNRS, INRA, Montpellier SupAgro, Montpellier, France
}

*Corresponding author: pierre.levasseur@irstea.fr, Irstea 361 rue J-F Breton, 34196 Montpellier cedex 5

\begin{abstract}
Poverty is a major determinant for pollution exposure, according to the US location choice literature. In this paper, we assess the impact of poverty on location choices in the European context. Our analysis is based on an original dataset of 1194 households living in polluted and non-polluted areas in three European countries: Spain, Portugal and France. We use instrumental variable strategies to identify the socioeconomic causes of location choices. We show that low education, wealth and income are main reasons for living in polluted areas. However, we also highlight several reasons why intermediate social groups (especially young couples) prefer living in polluted areas, such as greater housing surfaces or non-environmental amenities. Similarly, we show that middle-income households have lower move-out intentions than other income groups, next to households with strong community attachment or long lengths of residence in the area.
\end{abstract}

Keywords: soil pollution exposure; residential choice; socioeconomic status; environmental inequalities, instrumental variables strategy.

\section{Acknowledgements:}

This study was part of the SoilTakeCare project financed by INTERREG SUDOE funds 2017-2019. All ethical standards concerning data collection and analysis were respected. The database is anonymous and contains no personal information. The authors are responsible for all remaining errors. 


\section{INTRODUCTION}

Notwithstanding the strong development of locational choice models in recent decades, empirical evidence for the relationship between socioeconomic status and pollution exposure in Europe remains limited. In the US, the existing literature identifies a negative correlation between socioeconomic status and exposure to pollution (Jerrett et al., 2001, Banzhaf, Ma and Timmins, 2019). Some authors also find evidence of a causal effect (Banzhaf and Walsh 2008): richer households emigrate from polluted areas while poorer households immigrate to polluted areas; hence pollution is leading to social segregation. In Europe, the literature focused on the role of natural amenities, rather than pollution (but see Chanel et al. 2004), to explain patterns of social segregation. Results are ambiguous: Schaeffer et al. 2016, found that natural amenities increase the mutual segregation between executives and other workers in the French region of Marseille, but not in the region of Grenoble. In the Netherlands, van Duijn and Rouwendal (2013) showed that double earners prefer natural living environments while highly educated households placed more value on historical amenities. De Palma, Picard and Waddell (2007) highlight the important role of the noise disamenity, next to natural amenities and transport amenities, in location choices in the area of Paris. Schaeffer et al. (2016) conclude that location patterns ultimately depend on the interplay between natural and other amenities.

Several theoretical pathways may lead certain social groups to disproportionally live in polluted areas (Banzhaf, Ma and Timmins, 2019). First, industries tend to locate their polluting activities in 'favorable' geographic and economic areas, i.e. where land is available, the labor force is cheap and transport networks are well developed. Second, households choose their residential location depending on their willingness to pay (Tiebout 1956): even if lower-income households would prefer to live in a cleaner area, they are not willing to pay the higher price. Hence, in the long run, poorer households (as well as certain ethnic groups) end up in more polluted areas (Banzhaf and Walsh, 2013). Several multiplier effects can reinforce this pathway (Banzhaf, Ma and Timmins, 2019): people tend to adopt homophile behavior, i.e. they tend to live near other people with similar ethnic, sociodemographic or socioeconomic characteristics (Schirmer, Eggermond and Axhausen, 2014); residents may influence the local amenities 
of their community, which in turn plays on future arrivals. Next, households in polluted areas have generally less ability to influence governments and may less easily mobilize against existing rules in favor of industries (Banzhaf, Ma and Timmins, 2019, Gramaglia, 2015). Finally, residents may accept a certain level of pollution exposure in exchange for compensation provided by the polluting firm (Banzhaf, Ma and Timmins 2019, Phillimore and Bell, 2013), such as employment opportunities and direct investments in local amenities (e.g. parks, sports infrastructure and cultural centers). Compensations may also be set-up by the city hall, which may negotiate subsidies from the industry in exchange for the right to implant a polluting activity. French sociological studies show that polluted areas may specifically attract households with moderate standards of living (and not the poorest) because they provide several local amenities and affordable housing (Flanquart, Hellequin and Vallet, 2013).

Given the ambiguities concerning residential preferences in Europe, this article aims to contribute to the literature by quantitatively identifying the factors that determine the probability of living in polluted areas. In addition, we investigate the main determinants of the intention to move out of polluted areas in the next five years. Note that we analyze the admitted determinants (i.e. economic and social circumstances), besides the more hidden (and often omitted) determinants such as community attachment and risk taking behavior (Flanquart, Hellequin and Vallet, 2013, Dohmen et al. 2011). Our methodological approach, based on an instrumental variables (IV) strategy, addresses potential endogeneity issues due to reverse causality and unobserved heterogeneity in the relationship between household socioeconomic status, residential location and move-out intentions. To our best knowledge, the use of IV strategy in this context is new (see Bowen, 2002 ; Mitchell and Walker, 2005).

Our analysis is based on an original dataset of 1194 households and 2787 individuals in three study areas in Southwestern Europe (Spain, Portugal and France). Comparing the populations from several polluted areas with the populations from similar but non-polluted areas, our results emphasize the presence of strong environmental inequalities. The IV strategy shows that socioeconomic determinants (i.e. education, income and wealth) have negative effects on the probability of living in polluted areas. In contrast to the results from the US literature, we confirm qualitative findings that polluted areas also 
seem to be an alternative for young families with lower-middle incomes attracted by affordable housing facilities. Households that are less risk averse and more attached to their community also tend to live in polluted areas. Similarly, we find that middle-income families seem to see advantages in remaining in polluted areas.

The structure of the article is the following. In section 2, we describe the database and provide some contextual information about the case studies on which we base our analysis. In section 3 , we explain the methods we use to identify the main determinants of the probability of living and continuing to live in polluted areas versus living in cleaner ones. In section 4, we present our results and, in section 5, we conclude and discuss the related public policy implications.

\section{DATA}

\subsection{An original data set}

From October 2018 to January 2019, we conducted three household surveys of 1,194 households in France, Portugal and Spain, specifically designed to study the socioeconomic issues of pollution exposure. We collected data of 684 households (1589 individuals) in polluted areas and of 510 households (1198 individuals) in corresponding control areas, creating an original comparative dataset, the "Comparative Survey on Pollution Exposure "(CSPE). More precisely, the CSPE is representative of the following polluted areas: Viviez in France (156 households and 293 individuals); the municipality of Estarreja in Portugal (300 households and 739 individuals); and three villages of the Spanish Sierra Minera (Portman, Estrecho de San Ginès and Alumbres) located to the east of Cartagena (228 households and 557 individuals). The non-polluted control areas are: Montbazens in France (138 households and 309 individuals); the municipality of Vagos in Portugal (200 households and 437 individuals); and a group of villages (Portus, Galifa, Perin, La Corona, Cantera and Molinos Marfagones) located to the west of Cartagena in Spain (172 households and 452 individuals). Control areas were selected using region-specific literature. For example, Inácio, Neves and Pereira (2014) and Guihard-Costa et al. (2012) explain that Estarreja and Vagos had the same natural amenities before the installation of the chemical 
complex in Estarreja. Similarly, the French Institute of Public Health used Montbazens as control area to infer the health effects of pollution exposure in Viviez (Durand, Sauthier and Schwoebel, 2011). The polluted and control study areas are shown in Figure 1.

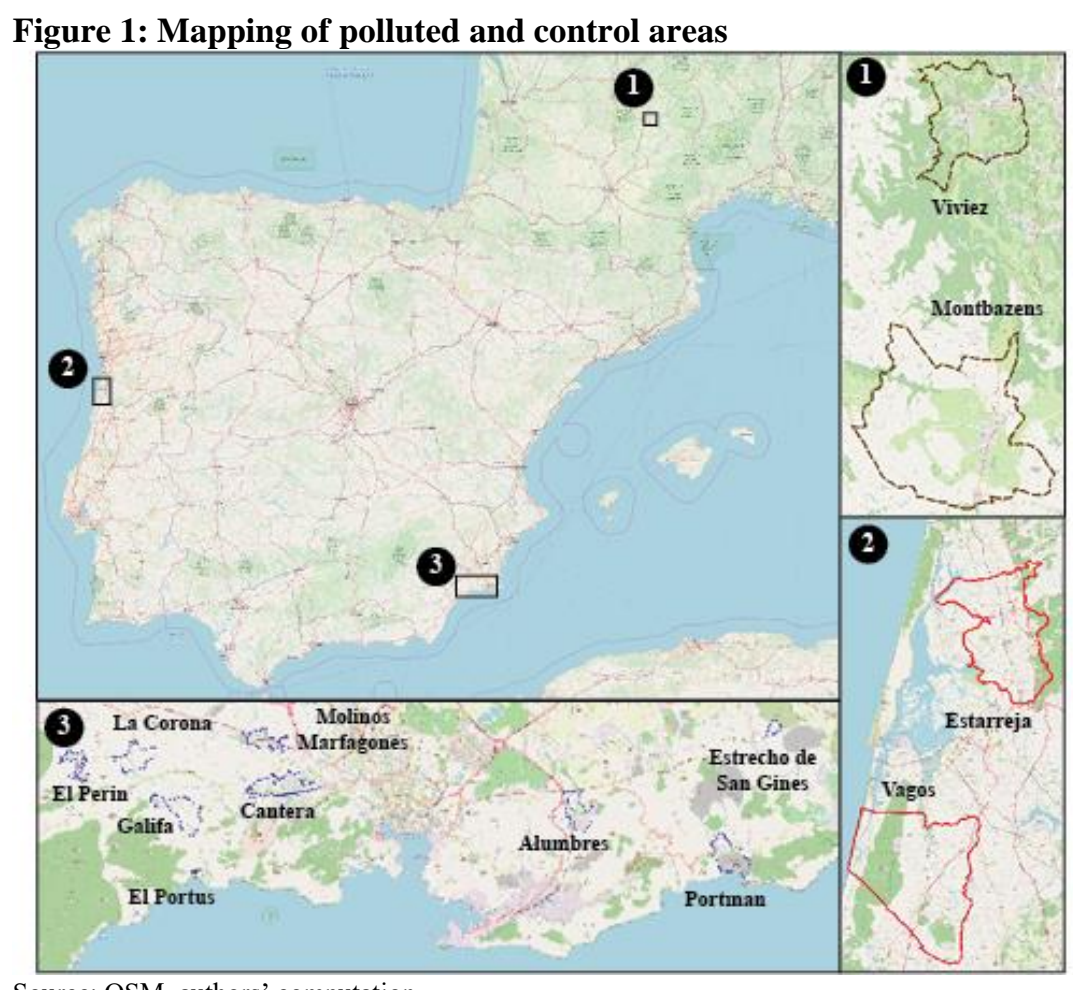

Source: OSM, authors' computation.

It is important to note that this quantitative survey was originally conducted to complete a set of welldocumented qualitative interviews. Although the results of the qualitative field campaigns are not directly included in this article, they greatly contributed to our understanding of the study context and issues.

\subsection{Context of the study areas}

The three study areas have different mining and industrial histories that make their comparison generalizable to a wide spectrum of pollution contexts. Based on the CSPE database, Table 1 provides mean-comparison tests between polluted sites and their respective control areas. Additional descriptive statistics about the study areas are provided in Appendix A. In the following, we describe some key characteristics of each area. 
Table 1: Mean-comparison tests between polluted and control areas

\begin{tabular}{|c|c|c|c|c|}
\hline & $\begin{array}{l}\text { Portman/ESG } \\
\text { vs. control }\end{array}$ & $\begin{array}{l}\text { Viviez } \\
\text { vs. control } \\
\end{array}$ & $\begin{array}{l}\text { Alumbres } \\
\text { vs. control } \\
\end{array}$ & $\begin{array}{l}\text { Estarreja } \\
\text { vs. control } \\
\end{array}$ \\
\hline \multicolumn{5}{|l|}{ Economic characteristics } \\
\hline Declared housing price (euros) & $-37326 * * *$ & $-81800 * * *$ & -4187 & -1089 \\
\hline Monthly renting price (euros) & $-62 * * *$ & $-104 * * *$ & -26 & 6.2 \\
\hline Monthly total income (euros) & $-504 * * *$ & $-561 * * *$ & -139 & $268 * * *$ \\
\hline Employment (proportion) & $-0.20 * * *$ & $-0.06 * * *$ & -0.07 & $0.16^{* * *}$ \\
\hline Unemployment and inactivity (proportion) & $0.20 * * *$ & $0.14 * *$ & 0.14 & $-0.17 * * *$ \\
\hline \multicolumn{5}{|l|}{ Local advantages } \\
\hline Perception of area attractiveness (1-to-5 scale) & -0.16 & $-1.21 * * *$ & $-0.53 * * *$ & 0.02 \\
\hline Perception of public services availability (1-to-5 scale) & $-1.06^{* * *}$ & $-0.75 * * *$ & $-0.41 * *$ & $0.20 * *$ \\
\hline Perception of shops and retails availability (1-to-5 scale) & $-0.36^{*}$ & $-1.09 * * *$ & -0.25 & $0.26^{* * *}$ \\
\hline \multicolumn{5}{|l|}{ Community life and involvement } \\
\hline Perception of social cohesion (1-to-5 scale) & -0.2 & $-0.51 * * *$ & $-0.40^{* *}$ & $-0.79 * * *$ \\
\hline Regularly participating in community events (proportion) & 0.06 & $-0.12 * *$ & $0.20 * *$ & 0.05 \\
\hline Involved in a local association (proportion) & $-0.11 *$ & $-0.09 *$ & -0.04 & $0.07 * *$ \\
\hline $\begin{array}{l}\text { Notes: } \\
\text { (1) Mean comparison tests }(\mathrm{H} 0: \mathrm{diff}=0) \text { are correc } \\
(\mathrm{H} 0: \text { ratio=1). Bilateral significance levels: } * * * 1 \\
\text { (2) Monthly renting price is hypothetic for housin }\end{array}$ & $\begin{array}{l}\text { qual variances } \\
0 \%\end{array}$ & standard de & D) ratio is & tly differen \\
\hline
\end{tabular}

The Spanish Sierra Minera is an ex-mining site that was particularly active between 1957 and 1990 due to the activity of a multinational company. Soils in the area show high concentrations of zinc, lead and cadmium. Since the decline of mining, few industrial alternatives have been set up and the development of tourism remains uncertain (Conesa, Schulin and Nowack, 2008 ; Banos-Gonzales and Baños Paez, 2013). By comparing Portman and Estrecho de San Ginès ESG to other towns located to the west of Cartagena (control group), Table 1 shows that lower housing prices, household incomes and employment rates characterize such ex-mining sites. Table 1 also identifies the lower perceived availability of services and retail outlets in these areas.

Alumbres is a small town located at the foot of the Sierra Minera (between Cartagena and La Union). This small town has prospered alongside the gradual development of a large petrochemical complex since 1950. Today, this industrial site includes an oil refinery, a gas plant, an electric power station that transforms fuel oils and gas, a factory producing white minerals oils, natural sulfonates and sulfuric acid, a fertilizer industry, and, a producer of lubrication bases. Alumbres is exposed to toxic winds of heavy metal residuals. As shown in Table 1, there is no significant difference between Alumbres and Molinos Marfagones (control group) in terms of the price of housing, employment, unemployment and perceived availability of retail outlets.

The Portuguese region of Estarreja has hosted an active industrial site since 1946. First, ammoniac, chlorine-sodium and PVC manufactures settled in Estarreja in 1946, 1956 and 1960, respectively. Then, 
since 1977, several petrochemical industries have begun their activity. Today, Estarreja hosts six complementary industries producing a large number of chemical products and other derived goods. Water cannels and ditches around the factory transport heavy metals and organic compounds. For instance, high concentrations of lead, mercury, arsenic and benzene have been found in the area. On the other hand, the presence of the industrial complex has made the area more dynamic and has improved the average socioeconomic and demographic characteristics of the area (Inácio, Neves and Pereira, 2014 ; Guihard-Costa et al., 2012). As suggested by Table 1, the municipality of Estarreja has better average characteristics than the municipality of Vagos (control area). Compared to the control area, residents are significantly richer in Estarreja, besides having better employment indicators and public facilities.

The case of Viviez in France marks the transition between a zinc smelting and a modern industry based on the processing of zinc and the recycling of industrial wastes. In 1855, a zinc smelter settled in Viviez because of its proximity to coal mines and rail facilities. In 1871, an international company undertook large-scale industrialization of the site by extracting, transforming and exporting zinc. In 1922, the site became a pioneer in adopting electrolytic techniques to chemically extract zinc from zinc blende. Although zinc extraction ended in 1987, the company continues to process zinc. In addition, the company helped develop new industries, namely the recycling of cadmium residuals and plastics. As a result of the zinc melting activity, the soils in the areas are contaminated with high concentrations of lead, cadmium and arsenic (Durand, Sauthier and Schwoebel, 2011). Considering the economic and community indicators listed in Table 1, Viviez looks more like Portman/ESG (an ex-mining site) than Alumbres and Estarreja (active industrial sites). Compared to Montbazens (control area), Viviez has lower housing prices, household incomes and employment rates, as well as a lower perceived availability of public services and retail outlets.

In a nutshell, our Southwestern European sample makes it possible to observe the three stages that characterize several polluted areas around the world: (i) ex-mining towns (Portman and ESG); (ii) a heavy metal industry undergoing technological reconversion (Viviez); and (iii) active (petro-)chemical 
complexes (Estarreja, and Alumbres). Interestingly, demographic and socioeconomic indicators tend to be worse in the two first groups and better in the third group. In Appendix A, we describe at more length the main reasons that motivate residents from Portman/ESG, Viviez, Alumbres and Estarreja to live in the area.

\section{METHODS}

In this article, we study the determinants of two types of outcome indicators. First, we create a binary variable "living in a polluted area" which takes the value 1 for households living in a study area, and zero for households living in a control area. This allows us to analyze the reasons why households live in each area. Next, we create a binary response variable that identifies households who plan to move out in the next five years. This allows us to explore potential dynamics in the environmental injustice process. In both cases, we estimate the probability of the outcome indicator being 1, using a Probit estimator. Referring to the theoretical pathways discussed in Section 2, our empirical analysis especially captures long-term effects between household socioeconomic indicators and pollution exposure. Indeed, the polluting sites we study have been settled since the 1950s (i.e. for more than two generations). In other words, even if the oldest residents might remain for emotional reasons, we assume that the majority of current residents already made their (re)location choice as a function of their economic constraints and their willingness to pay for a clean environment.

\subsection{Empirical challenges}

Apart from pollution and industrial features, our sample of polluted and non-polluted areas may initially differ in terms of ecological and historical attractiveness. ${ }^{1}$ In other words, it is impossible to be sure that our selected control areas are perfect counterfactuals of our selected polluted areas. A perfect

\footnotetext{
${ }^{1}$ Even if we methodically selected the set of control areas, environmental amenities, land availability, soil composition, cultural wealth and other points of interest may differ from those in the polluted areas, even before the arrival of polluting industries.
} 
counterfactual means that these control areas would evolve in the same way as the polluted areas if they had also benefited from the installation of an industrial site (or a mining company). Given that our control areas are potentially imperfect counterfactuals, simply comparing polluted and non-polluted samples might lead to a selection bias. Hence, the main challenge is to deal with endogeneity problems. First, our estimations could be biased because of the presence of reverse causality between household socioeconomic status and pollution exposure. Not only pollution reduces housing prices that potentially attracts poor households, but also polluting industries may emit residuals that are toxic for human health (Landrigan et al., 2018). Daily exposure to these toxic residuals may affect the capacity for socioeconomic advancement of residents through loss of productivity. Second, another source of endogeneity may originate from the omission of factors simultaneously correlated with household socioeconomic status and outcome indicators. In our context, we assume that heterogeneous environmental and geographical preferences may bias the estimates. Indeed, these preferences can be simultaneously correlated with socioeconomic status and the unexplained part of (re)location choice, and thus bias estimations. It is widely recognized that different social groups have specific tastes and perceptions about health, pollution and space and thus different ability to pay for desirable community amenities like a clean environment, natural spaces, nice landscapes, quality schools, public safety, employment accessibility and accessible retail outlets (Banzhaf, Ma and Timmins, 2019). To neutralize such a selection bias, we use an IV strategy that allows the effect of household socioeconomic status to be robustly assessed.

Another challenge is to correct the expected intra-group correlation within polluted villages that could reduce the variance of certain factors, and thus overestimate their significance. Indeed, it is well known that households tend to live among or relocate around groups of households with similar incomes (Schirmer, Eggermond and Axhausen, 2014). Moreover, the presence (or absence) of public facilities is an important predictor of residential choice (Guo and Bhat, 2007), which could reinforce the intracorrelation within an area. To control for the potential intra-group correlations within villages, cluster 
robust standard errors are systematically estimated at the village level (i.e. the standard errors are not calculated at the individual level but at the village level), see Wooldridge (2003)

\subsection{The model}

Based on Schirmer, Eggermond and Axhausen (2014), we frame our estimation models on the following dimensions measured at the household level: socioeconomic factors (income, education and wealth), demographic and housing factors (age group proportions, gender proportion, marital status, housing size and garden ownership), community-based factors (length of residence and family network), and respondent-based factors (risk taking behavior). Table B1 in the Appendix B describes the explanatory variables that we considered. We also tested other covariates such as housing price and employment indicators, but we do not include them in the model because of collinearity with indicators for socioeconomic status. More formally, we consider two structural equations with $\theta$ designing the functional form of the equation (i.e. a conditional maximum likelihood estimator). In a preliminary step, multivariate binomial regressions (Probit estimator) are performed for Eq.1 and Eq.2:

Eq.1: $\theta$ (LivingPollutedAreas $)=\beta_{0}+\beta_{1}$ SocioeconomicFactors $+\beta_{2}$ DemographicFactors + $\beta_{3}$ CommunityFactors $+\beta_{4}$ IndividualFactors $+\varepsilon$

Eq.2: $\theta$ (Move out $)=\beta_{0}+\beta_{1}$ SocioeconomicFactors $+\beta_{2}$ DemographicFactors + $\beta_{3}$ CommunityFactors $+\beta_{4}$ IndividualFactors $+\beta_{5}$ LivingPollutedAreas $+\beta_{6}[$ SocioeconomicFactors $*$ LivingPollutedAreas] $+\varepsilon$

Despite the comprehensive set of observed factors included in the analysis, these models potentially remain sensitive to endogeneity problems, mainly due to reverse causality and variations in unobserved individual preferences (landscape preference, geographical location, specific local amenities, etc.). Mathematically, $\beta_{1}$ is biased if socioeconomic factors are correlated with $\varepsilon$ (i.e. the unexplained part of the variance of the dependent variable). Therefore, to establish a causal inference regarding socioeconomic factors, we apply an IV strategy based on a control function method as follows (Wooldridge, 2010): 
Eq.3:

$\left\{\theta(\right.$ LivingPollutedAreas $)=\beta_{0}+\beta_{1}$ SocioeconomicFactors $+\beta_{2}$ DemographicFactors $+\beta_{3} \hat{\rho}+\varepsilon$

$\left\{\right.$ with $\mathrm{F}($ SocioeconomicFactors $)=\beta_{0}+\gamma_{1}$ Instruments $+\gamma_{2}$ DemographicFactors $+\rho$

Eq.4: $\left\{\begin{array}{c}\theta(\text { Move out })=\beta_{0}+\beta_{1} \text { SocioeconomicFactors }+\beta_{2} \text { Living PollutedAreas }+ \\ \beta_{3} \text { SocioeconomicFactors } * \text { LivingPollutedAreas }+\beta_{4} \text { DemographicFactors }+\beta_{5} \hat{\rho}+\varepsilon \\ \text { with } \mathrm{F}(\text { SocioeconomicFactors, SocioeconomicFactors } * \text { LivingPollutedAreas }) \\ =\beta_{0}+\gamma_{1} \text { Instruments }+\gamma_{2} \text { PollutionExposure }+\gamma_{3} \text { DemographicFactors }+\rho\end{array}\right.$

As suggested by Angrist and Pischke (2008), we only integrate exogenous control factors in the IV model in order to focus on the causal impacts of household education, wealth and income. Thus, we only control for demographic heterogeneity across households (i.e. age group proportions, gender proportion, marital status, housing size, and country fixed effects). Indeed, the inclusion of potential endogenous control factors (e.g. owning a garden, length of residence, family network and health risk behavior) could bias IV estimates insofar as we cannot be sure whether these factors are determinants or consequences of living in polluted areas.

We use the reported height (in meters) of the respondent, as well as the respondent's parental education (at least a high-school diploma), as IV to instrument socioeconomic factors. To implement overidentification tests, we also consider an additional instrument: the respondent's parental education (a dummy variable identifying if at least one of both parents completed high school).

While the correlation between the parent's and children's education is obvious, the literature abounds with works showing a strong relationship between individual height and socioeconomic status. Indeed, there is a vicious cycle between small height and poverty, namely due to the hazardous lifestyles of mothers during pregnancy, micronutrient deficiencies, schooling and labor market discrimination, and productivity loss (Marmot, 2015). In contrast, there is little evidence for a direct correlation between height and pollution exposure, at least concerning exposure to heavy metal residuals. Some evidence exists for an effect on height of intense inhalation of coal smoke during the English industrial revolution (Bailey, Hatton and Inwood, 2018), but, to our understanding, the effect of pollution exposure on height is mainly due to socioeconomic status. Indeed, as discussed by O'Neill et al. (2003), the poorest are 
likely to be the most exposed to pollution, with respect to the place of residence, work and behaviors, and hence, are the most affected by pollution-related diseases.

In the first step regression, we linearly regress socioeconomic factors on instruments and covariates. Then, the fitted error term from the first-step is included in the structural equation to neutralize the unobserved part of the variance of the dependent variable correlated with socioeconomic factors. In other words, assuming exogenous instruments, $\varepsilon$ is suitably independent of $\hat{\rho}$ and socioeconomic factors (i.e. socioeconomic factors are fully identified). This means that the model no longer has endogeneity problems and produces consistent estimates.

\section{RESULTS}

\subsection{Descriptive statistics}

As shown in Figure 2, the respondent's pollution perception of the area (measured with a 1-to-5 Likert scale) is strongly correlated with the probability of living in a polluted area.

\section{Figure 2: Respondent's pollution perception and probability of living in polluted areas}

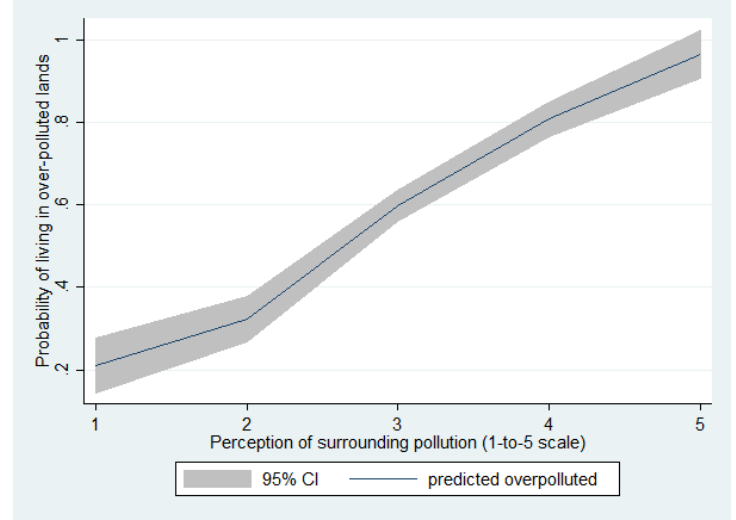

Source: Authors' calculation from the CSPE database.

Hence, the question is why people continue to live in polluted areas, even if they know about related pollution issues. Figure 3 shows that the probability of living in a polluted area decreases when household incomes differ from the average community income. As observed by Guo and Bhat (2007), the lower the absolute gap, the higher the risk of living in a polluted area. However, Figure 4 suggests that it is not mainly the poorest households (Q1) who live in polluted areas nor the richest households 
(Q4 and Q5), but a lower-middle class (Q2 and Q3). Nonetheless, this result should be interpreted with caution given the aforementioned endogeneity problems.

Figure 3: Income gaps in polluted areas

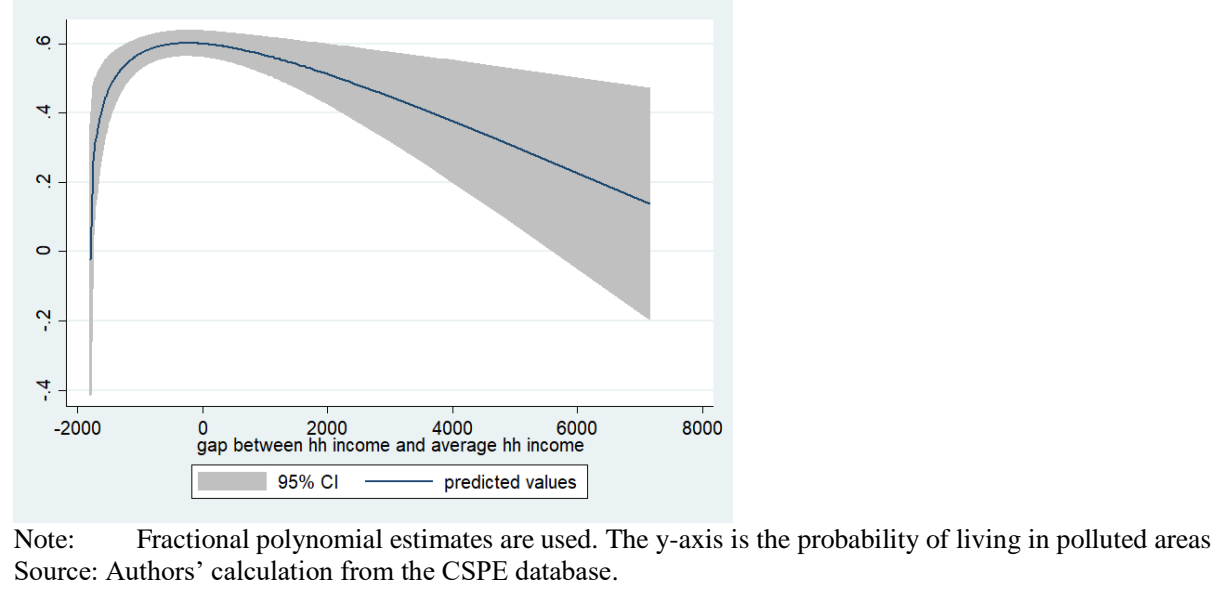

Source: Authors' calculation from the CSPE database.

Figure 4: Household incomes (in \$PPP) and risk of living in polluted areas

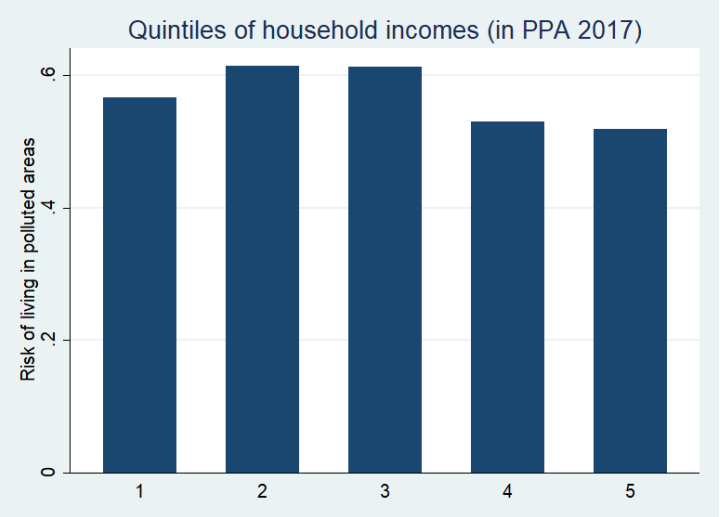

Source: Authors' calculation from the CSPE database.

\subsection{Why do people live in polluted areas?}

\section{Multivariate analysis}

We first conducted binomial multivariate regressions of the probability of living in polluted areas on several individual-, household- and community-based explanatory factors (Eq.1). Table B2 in the appendix shows average marginal effects (at the mean). The appendix also contains a more detailed discussion of these results.

As expected, socioeconomic factors are strong predictors of residential location choice. We find a Uinverted relationship between the wealth index or income and the probability of living in polluted areas. Housing size is also an important predictor of this probability, especially for young families with 
moderate wealth or income. Apart from socioeconomic factors, other factors have been controlled for: community attachment, the presence of a family network and the length or residence in the area increase the probability of living near polluted sites, while risk aversion in the domain of health risks decreases the probability of living there ${ }^{2}$. Having members of foreign origin in the household increases the probability of living in polluted areas. Likewise, single individuals and couples have a higher probability of living in polluted areas compared to individuals who suffered from marital upheavals (divorce, separation or widowhood).

To sum up, two groups of households disproportionally live in polluted areas (because of the better housing conditions, and probably of employment opportunities): (i) a group of young families with lower-middle incomes, and (ii) a more vulnerable group with a substantial proportion of single women. Note that both groups are characterized by low levels of education, in addition to being relatively poor considering the income and wealth distribution, which suggests important environmental inequalities in Southwestern Europe.

\section{Probit}

To test the impact of households' socioeconomic status on the probability of living in polluted areas, we apply a control function strategy: the instrumental variable Probit (see discussion in the next section). Table 3 depicts the results: marginal effects (at the mean) explaining the probability of living in polluted areas.

Columns 1 and 2 in Table 3 show that one extra educated member in the household reduces the probability of living in a polluted area by $25-37$ percentage points. This higher magnitude compared to Table B2 suggests that simple Probit estimates understate the negative impact of human capital on residential choices, probably due to a selection bias.

\footnotetext{
${ }^{2}$ We measure the environmental health risk aversion by asking the respondent to evaluate on a 1-to-5 Likert scale his/her willingness to live in a polluted area that may decrease by 5 years old his/her life expectancy.
} 
Table 3: Effects of socioeconomic status on the probability of living in polluted areas (conditional marginal effects at the mean point)

\begin{tabular}{|c|c|c|c|c|c|c|}
\hline & (1) & $(2)$ & (3) & (4) & $(5)$ & (6) \\
\hline \multirow[t]{2}{*}{ Number of children (lower than 17yo) } & -0.006 & -0.004 & 0.007 & 0.005 & 0.000 & -0.001 \\
\hline & $(-0.22)$ & $(-0.17)$ & $(0.42)$ & $(0.28)$ & $(0.00)$ & $(-0.05)$ \\
\hline \multirow[t]{2}{*}{ Number of young adults (18-29yo) } & $0.226 * * *$ & $0.166^{* *}$ & $0.057 * *$ & $0.063 * *$ & $0.126 * * *$ & $0.105^{*}$ \\
\hline & $(5.47)$ & $(2.43)$ & $(2.46)$ & $(2.37)$ & $(3.02)$ & $(1.88)$ \\
\hline \multirow[t]{2}{*}{ Number of lower-middle age adults (30-44yo) } & $0.172 * * *$ & $0.114 * *$ & $0.072 * *$ & $0.071 * *$ & $0.163 * * *$ & $0.122 *$ \\
\hline & $(3.64)$ & $(2.04)$ & $(2.09)$ & $(1.98)$ & $(3.63)$ & $(1.78)$ \\
\hline \multirow[t]{2}{*}{ Number of higher middle age adults (45-64yo) } & $0.079 * *$ & 0.031 & 0.047 & 0.038 & 0.068 & 0.032 \\
\hline & $(2.00)$ & $(0.70)$ & $(1.45)$ & $(1.18)$ & $(1.60)$ & $(0.51)$ \\
\hline \multirow[t]{2}{*}{ Number of old adults (higher than 65yo) } & 0.011 & -0.000 & -0.044 & -0.037 & 0.010 & -0.002 \\
\hline & $(0.36)$ & $(-0.01)$ & $(-1.51)$ & $(-1.37)$ & $(0.24)$ & $(-0.03)$ \\
\hline \multirow[t]{2}{*}{ Number of male members } & -0.035 & -0.040 & -0.011 & -0.020 & -0.015 & -0.019 \\
\hline & $(-1.17)$ & $(-1.27)$ & $(-0.43)$ & $(-0.75)$ & $(-0.66)$ & $(-0.71)$ \\
\hline Respondent is in a couple (dummy) & 0.047 & $0.053 *$ & $0.192 * * *$ & $0.200 * * *$ & $0.201 * * *$ & $0.191 * * *$ \\
\hline \multirow[t]{2}{*}{ Respondent is single (dummy) } & 0.021 & 0.037 & $0.125 * * *$ & $0.145^{* * *}$ & $0.155^{* *}$ & $0.164 * * *$ \\
\hline & $(0.36)$ & $(0.62)$ & $(3.38)$ & $(3.35)$ & $(2.48)$ & $(2.65)$ \\
\hline \multirow[t]{2}{*}{ Number of rooms } & $0.055^{* * *}$ & $0.055^{* * *}$ & $0.085 * * *$ & $0.088^{* * *}$ & $0.076^{* * *}$ & $0.071 * * *$ \\
\hline & $(3.96)$ & $(3.30)$ & $(6.55)$ & $(5.46)$ & $(5.17)$ & $(3.99)$ \\
\hline \multirow[t]{2}{*}{ Number of members who obtained a high school grade } & $-0.380 * * *$ & $-0.253 * *$ & & & & \\
\hline & $(-4.83)$ & $(-2.55)$ & & & & \\
\hline \multirow[t]{2}{*}{ Wealth index } & & & $-0.251 * * *$ & $-0.229 * * *$ & & \\
\hline & & & $(-6.68)$ & $(-4.55)$ & & \\
\hline \multirow[t]{2}{*}{$\ln ($ incomePPP) } & & & & & $-0.540 * * *$ & $-0.421 * * *$ \\
\hline & & & & & $(-5.53)$ & $(-2.97)$ \\
\hline Country fixed effects & Yes & Yes & Yes & Yes & Yes & Yes \\
\hline Observations & 1,147 & 1,098 & 1,147 & 1,098 & 943 & 911 \\
\hline $\begin{array}{l}\text { Amemiya-Lee-Newey overidentification test }(\mathrm{H} 0=\text { error term } \\
\text { uncorrelated to instruments }) \text { - (p-value) }\end{array}$ & & $(0.161)$ & & $(0.564)$ & & $(0.292)$ \\
\hline Hansen J statistic (overidentification test of all instruments) & & 1.45 & & 0.175 & & 0.92 \\
\hline (p-value) & & $(0.229)$ & & $(0.676)$ & & $(0.339)$ \\
\hline Rho $(\hat{\rho})$ & $0.581 * * *$ & $0.352 *$ & $0.722 * * *$ & $0.655^{* * *} *$ & $0.576 * * *$ & $0.447 * *$ \\
\hline Wald test of exogeneity $(\mathrm{H} 0=$ no endogeneity) & 10.13 & 3.76 & 12.66 & 9.59 & 12.27 & 5.83 \\
\hline (p-value) & $(0.002)$ & $(0.052)$ & $(0.000)$ & $(0.002)$ & $(0.001)$ & $(0.0158)$ \\
\hline $\begin{array}{l}\text { F-statistics on the excluded instruments from the first- } \\
\text { stages }\end{array}$ & 18.65 & 16.65 & 12.90 & 21.05 & 22.51 & 35.20 \\
\hline
\end{tabular}

Notes: (1) We use as instrumental variables (IV): (i) height in meters of the respondent (in each specification); (ii) parental education level (at least a high-school degree) of the respondent (in specifications 2, 4 and 6).

(2) Robust standard errors are reported correcting intra-village correlation. Significance levels are: ***1\%, **5\%, *10\%,

(3) Wealth index is the sum of the following owned (or not) assets: former house, second house, car, air conditioner, computer, cellphone and financial assets. Thus, the wealthiest households have a score of 7 while the most deprived household a score of 0 . Then, this score is logtransformed by adding 1 for avoiding the generation of missing values (i.e. $\log (0)=$.). We also tested the impact of this variable employing a logtransformation. However, the results remain the same.

(4) IV-Probit regressions are employed using a Maximum Likelihood estimator. We also tested the Newey's two-step estimator and the results remain similar.

Source: Authors' calculation from the CSPE database.

Regarding the impacts of household economic status, we find that household wealth and income negatively affect the probability of living in a polluted area: one extra owned asset reduces the probability of living in polluted areas by $23-25$ percentage points and a $10 \%$ increase in incomes reduces this probability by 4-5 percentage points. Hence, household economic status has a strong negative impact on the risk of living in polluted areas. Results also show that young and lower-middle aged people tend 
to live more often in polluted areas, either in a couple or as singles. Likewise, coefficients for housing size are significant and positive in all fitted models, corroborating results from the simple Probit model that households with lower socioeconomic status can live in larger houses at affordable prices in polluted areas.

Compared to the results presented in Table B2, we do not observe any stronger representation of a lowermiddle social class in polluted areas. The difference in results may be due to unobserved factors correlated with household socioeconomic status. Indeed, according to the sociological literature (Flanquart, Hellequin and Vallet, 2013), polluted areas have several omitted characteristics that may attract lower-middle social classes to live there, such as employment opportunities and accessibility, housing facilities and other advantages (e.g. community satisfaction).

\section{Validation of the Instrumental Variable strategy}

Empirical estimates suggest that our two instruments satisfy the two requirements of suitable instruments (Wooldridge 2010) ${ }^{3}$. First, the instrument is a non-weak predictor of the endogenous variable, conditional on control variables. As shown in Table B3 in the Appendix, even after controlling for exogenous covariates, the height of the respondent and the education of his/her parents are both significant predictors of household socioeconomic status. For example, we can see that one extra centimeter in the respondent's height increases the household income by around $1 \%$. It is reassuring to see in Table 3 that all first-stage F-statistics on the excluded instrument are relatively high. Second, the exclusion restriction assumption can be partially tested when the endogenous regressor is overidentified. A correlation between the instruments and omitted factors related to the probability of living

\footnotetext{
${ }^{3}$ To be suitable, an instrument must meet two conditions: (i) it must be a non-weak predictor of the endogenous variable conditional on control variables; and (ii) it must not be directly related to the error component in the structural equation (i.e. not be correlated with the unexplained part of the probability of living in a polluted area). The second condition, called exclusion restriction assumption, means that our instruments should not directly correlate with the probability of living in a polluted area through channels other than the household socioeconomic status (Wooldridge, 2010).
} 
in a polluted area might cast doubt on the validity of selected instruments. However, over-identification tests suggest the absence of correlation between the error terms of the structural equation and the instruments (Table 3). Consequently, we can assume that our instruments are strong (i.e. meet the first requirement) and exogenous (i.e. meet the second requirement). Furthermore, by running a reducedform regression of the dependent variable on the instruments and covariates (Table B4 of the Appendix), we are able to appreciate the expression of the causal effect of interest. Indeed, we find a significant correlation between our instruments and the probability of living in a polluted area, which is proportional to the effect of household socioeconomic status on residential location. This means that when household socioeconomic status is omitted, we continue to observe its influence on the dependent variable through the instruments. ${ }^{4}$ In Table 3, Wald tests of exogeneity measure the relevance of using a control function approach (i.e. of including the fitted error term from the first-step regression, $\hat{\rho}$, in the structural equation). These tests lead us to reject the null hypothesis of no correlation between $\hat{\rho}$ and the probability of living in a polluted area. In addition, the fitted coefficient of $\hat{\rho}$ (i.e. $\beta_{3}$ in Eq.3) is significant. This means that there is enough information in the sample to conclude on the presence of endogeneity and thus justify our intention to treat related bias.

\subsection{What factors motivate people to move out of polluted areas?}

To identify the determinants that influence the decision to leave a polluted area, we regress the intention to move out in the next five years on several factors interacted with the fact of living in a polluted area versus living in a cleaner area. We consider that such a model specification (Eq.2) is not affected by endogeneity-related biases. Indeed, an inverse causality bias is merely impossible since the intention to move out cannot affect current income, education or wealth. In addition, we find no reason to think that unobserved factors are simultaneously correlated with socioeconomic status and emigration intentions. In fact, by applying a similar IV strategy as in the previous subsection (Eq.4), the Wald test of exogeneity

\footnotetext{
${ }^{4}$ As Angrist and Pischke (2008, p.157) argue, "if you can't see the causal relation of interest in the reduced form, it's probably not there".
} 
suggests that an ordinary binomial regression model (i.e. Probit) does not suffer from potential endogeneity problems.

Table 4 shows marginal effects (at the mean) of the intention to move-out in the next 5 years. Several divergences appear between polluted areas and clean areas. First, compared to control areas, living in polluted areas increases the intention to move out in the next five years by 3 percentage points (Column 1). Focusing on interaction terms, we observe that both the wealth index and income groups affect the intention to leave a polluted area. In Column 2, while an extra owned asset reduces the move-out intention in clean areas by 1.3 percentage point, in polluted areas such an extra asset increases the probability by 0.4 percentage points. Column 2 also hypothetically indicates that, among extremely deprived households (with not even one owned asset), living in a polluted area does not affect move-out intentions. In Column 3, we find that, in polluted areas, households belonging to the third and the fourth quintiles have lower move-out intentions (around -4 percentage points) compared to households belonging to the richest income category (Q5). These results emphasize a nonlinear relationship between household socioeconomic status and the intention to leave a polluted area.

Regarding demographic factors, Column 4 in Table 4 shows that the average age of adult household members significantly reduces the motivation to move out in households living in polluted areas: 10 extra years in age reduces move-out intentions by 2 percentage points, compared to households living in cleaner control areas. This result is consistent with the aging theories of mobility and pollution perception: older individuals are less sensitive to pollution and related risks than younger ones, besides being less mobile (Lee and Waddell, 2010). ${ }^{5}$ Community attachment might also explain why people

\footnotetext{
${ }^{5}$ Note that, even if being older reduces the probability of living in polluted areas (as can be seen in Table 2), household average age can increase the intention to stay. It is likely that older people who chose to stay in polluted areas (before the survey collection) are the most attached to (or trapped in) the community. Hence, these stayers are likely to remain attached (or trapped) when we ask for move-out intention.
} 
Table 4: Factors correlated to the intention to move out in the next 5 years, average marginal effects based on Eq.2

\begin{tabular}{|c|c|c|c|c|c|}
\hline & $(1)$ & $(2)$ & (3) & $(4)$ & $(5)$ \\
\hline Average age of adults (in years) & $\begin{array}{l}-0.002 * * * \\
(-3.32)\end{array}$ & $\begin{array}{l}-0.002 \text { *** } \\
(-3.44)\end{array}$ & $\begin{array}{l}-0.001 * * \\
(-2.57)\end{array}$ & $\begin{array}{l}0.000 \\
(0.04)\end{array}$ & $\begin{array}{l}-0.000 \\
(-0.10)\end{array}$ \\
\hline Number of male members & $\begin{array}{l}0.000 \\
(0.03)\end{array}$ & $\begin{array}{l}0.000 \\
(0.03)\end{array}$ & $\begin{array}{l}0.005 \\
(0.70)\end{array}$ & $\begin{array}{l}0.005 \\
(0.76)\end{array}$ & $\begin{array}{l}0.005 \\
(0.90)\end{array}$ \\
\hline Respondent is in a couple (dummy) & $\begin{array}{l}-0.009 \\
(-0.62)\end{array}$ & $\begin{array}{l}-0.010 \\
(-0.73)\end{array}$ & $\begin{array}{l}-0.008 \\
(-0.40)\end{array}$ & $\begin{array}{l}-0.004 \\
(-0.18)\end{array}$ & $\begin{array}{l}-0.003 \\
(-0.17)\end{array}$ \\
\hline Respondent is single (dummy) & $\begin{array}{l}0.040^{*} \\
(1.74)\end{array}$ & $\begin{array}{l}0.040^{*} \\
(1.75)\end{array}$ & $\begin{array}{l}0.041 * \\
(1.82)\end{array}$ & $\begin{array}{l}0.044^{*} \\
(1.86)\end{array}$ & $\begin{array}{l}0.047 * * \\
(2.07)\end{array}$ \\
\hline Number of members with foreign parents & $\begin{array}{l}0.014 \\
(1.43)\end{array}$ & $\begin{array}{l}0.014 \\
(1.38)\end{array}$ & $\begin{array}{l}0.016 \\
(1.13)\end{array}$ & $\begin{array}{l}0.016 \\
(1.20)\end{array}$ & $\begin{array}{l}0.014 \\
(1.12)\end{array}$ \\
\hline Number of rooms & $\begin{array}{l}-0.002 \\
(-0.40)\end{array}$ & $\begin{array}{l}-0.002 \\
(-0.47)\end{array}$ & $\begin{array}{l}-0.005 \\
(-0.82)\end{array}$ & $\begin{array}{l}-0.005 \\
(-0.76)\end{array}$ & $\begin{array}{l}-0.005 \\
(-0.86)\end{array}$ \\
\hline Having a garden (dummy) & $\begin{array}{l}-0.029 \\
(-1.15)\end{array}$ & $\begin{array}{l}-0.028 \\
(-1.11)\end{array}$ & $\begin{array}{l}-0.016 \\
(-0.74)\end{array}$ & $\begin{array}{l}-0.017 \\
(-0.82)\end{array}$ & $\begin{array}{l}-0.013 \\
(-0.73)\end{array}$ \\
\hline Presence of family members around & $\begin{array}{l}-0.030^{*} \\
(-1.81)\end{array}$ & $\begin{array}{l}-0.031 * \\
(-1.92)\end{array}$ & $\begin{array}{l}-0.023 \\
(-1.25)\end{array}$ & $\begin{array}{l}-0.021 \\
(-1.18)\end{array}$ & $\begin{array}{l}-0.019 \\
(-1.23)\end{array}$ \\
\hline Lifetime in the area (in year) & $\begin{array}{l}-0.001 * * \\
(-2.30)\end{array}$ & $\begin{array}{l}-0.001 * * \\
(-2.29)\end{array}$ & $\begin{array}{l}-0.001 * * * \\
(-3.19)\end{array}$ & $\begin{array}{l}-0.002 * * * \\
(-4.36)\end{array}$ & $\begin{array}{l}-0.002 * * * \\
(-4.01)\end{array}$ \\
\hline Willingness to live in a polluted land that decreases life expectancy by & $\begin{array}{l}0.006 \\
(0.74)\end{array}$ & $\begin{array}{l}0.005 \\
(0.62)\end{array}$ & $\begin{array}{l}0.001 \\
(0.13)\end{array}$ & $\begin{array}{l}0.000 \\
(0.02)\end{array}$ & $\begin{array}{l}-0.003 \\
(-0.34)\end{array}$ \\
\hline Area attractiveness index (3-to-15 scale) & $\begin{array}{l}-0.007 * * * \\
(-3.89)\end{array}$ & $\begin{array}{l}-0.006 * * * \\
(-3.59)\end{array}$ & $\begin{array}{l}-0.007 * * * \\
(-3.76)\end{array}$ & $\begin{array}{l}-0.007 * * * \\
(-3.70)\end{array}$ & $\begin{array}{l}-0.006^{* * *} * \\
(-3.41)\end{array}$ \\
\hline $\begin{array}{l}\text { Perceived knowledge about anti-pollution protection methods (1-to-5 } \\
\text { scale) }\end{array}$ & $\begin{array}{l}-0.008^{*} \\
(-1.84)\end{array}$ & $\begin{array}{l}-0.008^{*} \\
(-1.79)\end{array}$ & $\begin{array}{l}-0.008 \\
(-1.44)\end{array}$ & $\begin{array}{l}-0.008 \\
(-1.53)\end{array}$ & $\begin{array}{l}-0.009 * \\
(-1.81)\end{array}$ \\
\hline Associative involvement (dummy) & $\begin{array}{l}0.024 \\
(1.20)\end{array}$ & $\begin{array}{l}0.024 \\
(1.29)\end{array}$ & $\begin{array}{l}0.025 \\
(1.10)\end{array}$ & $\begin{array}{l}0.022 \\
(1.06)\end{array}$ & $\begin{array}{l}-0.020 \\
(-0.59)\end{array}$ \\
\hline Social cohesion perception (1-to-5 scale) & $\begin{array}{l}-0.017 * * * \\
(-2.74)\end{array}$ & $\begin{array}{l}-0.017 * * * \\
(-2.84)\end{array}$ & $\begin{array}{l}-0.015^{* *} \\
(-2.34)\end{array}$ & $\begin{array}{l}-0.015^{* *} \\
(-2.31)\end{array}$ & $\begin{array}{l}-0.016^{* * * *} \\
(-2.73)\end{array}$ \\
\hline Regular participation in community parties (dummy) & $\begin{array}{l}-0.016 \\
(-1.06)\end{array}$ & $\begin{array}{l}-0.016 \\
(-1.09)\end{array}$ & $\begin{array}{l}-0.010 \\
(-0.63)\end{array}$ & $\begin{array}{l}-0.012 \\
(-0.75)\end{array}$ & $\begin{array}{l}-0.048 * * \\
(-2.25)\end{array}$ \\
\hline Number of members who obtained a high school grade & $\begin{array}{l}-0.001 \\
(-0.14)\end{array}$ & $\begin{array}{l}0.001 \\
(0.10)\end{array}$ & $\begin{array}{l}-0.011^{*} \\
(-1.73)\end{array}$ & $\begin{array}{l}-0.010^{*} \\
(-1.73)\end{array}$ & $\begin{array}{l}-0.012 * * \\
(-2.16)\end{array}$ \\
\hline Wealth index (0-to-7 score) & $\begin{array}{c}-0.002 \\
(-0.36)\end{array}$ & $\begin{array}{l}-0.013 * \\
(-1.73)\end{array}$ & & & \\
\hline Income Quintile 1 & & & $\begin{array}{l}-0.009 \\
(-0.28)\end{array}$ & $\begin{array}{l}-0.016 \\
(-0.47)\end{array}$ & $\begin{array}{l}-0.029 \\
(-0.83)\end{array}$ \\
\hline Income Quintile 2 & & & $\begin{array}{l}0.002 \\
(0.06)\end{array}$ & $\begin{array}{l}-0.000 \\
(-0.01)\end{array}$ & $\begin{array}{l}-0.009 \\
(-0.23)\end{array}$ \\
\hline Income Quintile 3 & & & $\begin{array}{l}0.015 \\
(0.29)\end{array}$ & $\begin{array}{l}0.021 \\
(0.40)\end{array}$ & $\begin{array}{l}0.010 \\
(0.24)\end{array}$ \\
\hline Income Quintile 4 & & & $\begin{array}{l}-0.012 \\
(-0.49)\end{array}$ & $\begin{array}{l}-0.010 \\
(-0.41)\end{array}$ & $\begin{array}{l}-0.017 \\
(-0.87)\end{array}$ \\
\hline Polluted area (dummy) & $\begin{array}{l}0.029 * \\
(1.90)\end{array}$ & $\begin{array}{c}-0.033 \\
(-0.91)\end{array}$ & $\begin{array}{l}\text { 0.076** } \\
(2.12)\end{array}$ & $\begin{array}{l}0.145 * * * \\
(2.87)\end{array}$ & $\begin{array}{l}0.085 * * \\
(1.98)\end{array}$ \\
\hline Wealth*PollutedArea & & $\begin{array}{l}\text { 0.017* } \\
(1.75)\end{array}$ & & & \\
\hline IncomeQ1*PollutedArea & & & $\begin{array}{l}-0.038 \\
(-1.25)\end{array}$ & $\begin{array}{l}-\mathbf{0 . 0 2 7} \\
(-0.77)\end{array}$ & $\begin{array}{l}-0.015 \\
(-0.40)\end{array}$ \\
\hline IncomeQ2*PollutedArea & & & $\begin{array}{l}-0.033 \\
(-1.09)\end{array}$ & $\begin{array}{l}-0.028 \\
(-0.84)\end{array}$ & $\begin{array}{l}-0.022 \\
(-0.66)\end{array}$ \\
\hline IncomeQ3*PollutedArea & & & $\begin{array}{l}-0.059 * * \\
(-2.05)\end{array}$ & $\begin{array}{l}-0.058 * * \\
(-2.16)\end{array}$ & $\begin{array}{l}-0.053 * * \\
(-2.23)\end{array}$ \\
\hline IncomeQ4*PollutedArea & & & $\begin{array}{l}-\mathbf{0 . 0 5 0} * * * \\
(-2.70)\end{array}$ & $\begin{array}{l}-0.047 * * * \\
(-2.70)\end{array}$ & $\begin{array}{l}-0.042 * * * \\
(-2.61)\end{array}$ \\
\hline AverageAge*PollutedArea & & & & $\begin{array}{l}-0.002 * * \\
(-2.55)\end{array}$ & $\begin{array}{l}-0.002 * * \\
(-2.25)\end{array}$ \\
\hline Lifetime*PollutedArea & & & & $\begin{array}{l}0.001 * * \\
(2.08)\end{array}$ & $\begin{array}{l}\text { 0.001* } \\
(1.85)\end{array}$ \\
\hline Association*PollutedArea & & & & & $\begin{array}{l}\text { 0.105* } \\
(1.77)\end{array}$ \\
\hline CommunityParties*PollutedArea & & & & & $\begin{array}{l}0.098 * * \\
(2.03) \\
\end{array}$ \\
\hline Country fixed-effect & Yes & Yes & Yes & Yes & Yes \\
\hline Observations & 1,099 & 1,099 & 900 & 900 & 900 \\
\hline Pseudo R-square & 0.176 & 0.180 & 0.211 & 0.218 & 0.238 \\
\hline
\end{tabular}

Notes: (1) Standard errors are robust to intra-group correlation. Significance levels are: ***1\%, **5\%, *10\%,

(2) Wealth index is the sum of the following owned (or not) assets: former house, second house, car, air conditioner, computer, cellphone and financial assets. Thus, the wealthiest households have a score of 7 while the most deprived household a score of 0 . (3) Area attractiveness index is the sum of the following 1-to-5 perception scores: global attractiveness, availability of public services and availability of shops and retails. Thus, areas perceived as the most attractive have a score equal to 15, while areas perceived as the most deprived have a score of 3. Source: Authors' calculation from the CSPE database. decide to continue living in the same place. Even if the effect of the length of residence appears to be

stronger in unpolluted areas than in polluted ones, the length of residence also reduces move-out 
intentions in polluted areas (Column 4). While living 10 extra years in an unpolluted area reduces moveout intention by 2 percentage points, in polluted areas, such an increase reduces the move-out intention by 1 percentage point. Finally, in Column 5, we find a surprising result concerning community involvement. While participation in community events increases the intention to stay in an unpolluted area by 4.7 percentage points, the same participation increases the intention to leave a polluted area by 5 percentage points. We observe similar results concerning involvement in associative life. These findings highlight the presence of a link between community involvement and sensitivity to pollution, as mentioned by Chanel et al. (2004). Moreover, these results also emphasize the level of social exclusion of several households who prefer to stay than to move out.

Table B4 in the Appendix shows variables that do not influence move-out intentions differently between polluted and non-polluted areas. In particular, the attractiveness of an area and the perception of social cohesion are two of such factors. ${ }^{6}$ In the same way, household education, marital status and the presence of a family network affect the intention to move out independently of the residential location. Anywhere, living close his/her family reduces move-out intentions, whereas being single and educated increases mobility intention, probably due to better social and professional opportunities elsewhere.

\section{DISCUSSION AND CONCLUSION}

Our study identified the main determinants that explain why households live and continue to live near polluted sites in Southwestern Europe. We implemented an IV procedure, which is rarely done in the connected literature. Globally, our results corroborate the existence of socio-environmental inequalities in the European context. First, we find that household education reduces the risk of living in polluted areas. In line with the results from the US literature, environmental disamenities tend to ward off educated households, whereas environmental amenities attract these population groups (Waltert and

\footnotetext{
${ }^{6}$ The absence of heterogeneous effects according to pollution exposure might be due to the fact that the attractiveness index and the perception of social cohesion are collinear with residential location. As shown in Table 1, polluted areas are generally perceived as less attractive and less socially cohesive, which probably affects the probability of living there.
} 
Schläpfer, 2010). However, our data distribution suggests that the economic segregation is not as linear as in the US. The multivariate analysis shows that a lower-middle income class disproportionally lives in polluted areas in Southwestern Europe. Note that housing size significantly increases the probability of living in polluted areas for this social group. In addition, there are higher proportions of couples and young adults who live in polluted areas to benefit from bigger houses. Hence, as pertinently discussed by Flanquart, Hellequin and Vallet (2013), polluted areas may constitute an acceptable residential alternative for households with moderate standards of living insofar as such towns provide several amenities at an affordable price. The overrepresentation of a lower-middle class in larger houses also matches the assumption of Banzhaf, Ma and Timmins (2019) about the existence of compensations and benefits for households who accept to live near a polluting industry. Note that these unobserved local amenities might be a source of endogeneity and could bias the fitted coefficients of socioeconomic factors. Indeed, when we opt for an endogeneity-corrector approach (the IV strategy), we find a negative and linear impact of household income and wealth on the risk of living in polluted areas. Finally, we find a higher proportion of households with members of foreign origin in polluted areas compared to in control areas. This fact is consistent with a study on France that showed a strong spatial correlation between towns with a high proportions of immigrant residents and the presence of hazardous sites (Laurian, 2008).

In terms of move-out intentions, we detect some nonlinearities that might modify the linear vision of environmental inequalities. In accordance with the mainstream theory, it is particularly the richest households who plan to move out, probably because of their greater financial capacities and employment opportunities. Inversely, the most materially deprived households have no move-out intentions given their limited funding capacities and opportunities. Moreover, among polluted areas, we observe that people who are not involved in the community life have lower move-out intentions than people who are involved in community life. To us, these findings suggest the disproportionate presence of socially excluded groups in polluted areas with no move-out intentions. Our results emphasize the fact that the general equilibrium theorized by Tiebout (1956) has still not been reached in our sample of polluted 
areas. However, between the two socioeconomic antipodes, there is a middle class with strong intentions to remain in polluted areas. As we previously suspected, one can assume that polluted areas in Southwestern Europe provide some amenities that particularly attract lower-middle classes. Another interesting result underlines the importance of aging and length of residence as significant determinants of the intention to remain in polluted areas. This result is in line with the sociological literature. In the US context, Shriver and Kennedy (2005, p.495) argue that "long-term residents express less concern over environmental hazards because they are far more attached to their local communities". In France, Flanquart, Hellequin and Vallet (2013) observe that populations living alongside hazardous industrial sites feel a strong community attachment.

The main limitation of this study is linked to the fact that it is measuring local effects. Indeed, strictly speaking, our results are only valid for our study areas in Southwestern Europe. However, the industrial heterogeneity of our sample makes our estimate generalizable to a wide spectrum of polluted areas. Of course, further analyses of the determinants of the socio-environmental segregation in Europe should be conducted in other contexts (e.g. different case studies and different outcome indicators).

The fact that hazardous polluted areas tend to become economically attractive for lower socioeconomic groups may be a dramatic public health issue, given that lower social classes tend to have more children. Additional studies should also assess the health and productivity effects of pollution exposure in addition to the influence of socioeconomic status on such effects. Finally, our results imply that health policies or recommendations for averting behaviour should be targeted in particular towards lower-middle class families, which are the most likely to be attracted by employment and housing opportunities in polluted areas. 


\section{REFERENCES}

Angrist Joshua D., PischKe Jörn-Steffen, 2008, Mostly Harmless Econometrics: An Empiricist's Companion, Princeton University Press, $393 \mathrm{p}$.

Bailey Roy E., Hatton Timothy J., Inwood Kris, 2018, “Atmospheric Pollution, Health, and Height in Late Nineteenth Century Britain”, The Journal of Economic History, 78(4), pp. 1210-1247.

Banos-Gonzales Isabel, Baños Paez Pedro, 2013, Portmán: De el Portus Magnus del Mediterráneo Occidental a la Bahía Aterrada | Ediciones de la Universidad de Murcia (Editum), Ediciones de la Universidad de Murcia, Murcia, España, Baños Paez.

Banzhaf H. Spencer, Walsh Randall P., 2008, "Do People Vote with Their Feet? An Empirical Test of Tiebout", American Economic Review, 98(3), pp. 843-863.

BANZhaf H. Spencer, WALSh Randall P., 2013, "Segregation and Tiebout sorting: The link between place-based investments and neighborhood tipping", Journal of Urban Economics, 74, pp. 83-98.

Banzhaf Spencer, MA Lala, Timmins Christopher, 2019, "Environmental Justice: the Economics of Race, Place, and Pollution", The Journal of Economic Perspectives: A Journal of the American Economic Association, 33(1), pp. 185-208.

Bowen William, 2002, “An analytical review of environmental justice research: what do we really know?”, Environmental Management, 29(1), pp. 3-15.

Chanel Olivier, Faugere Elsa, Geniaux Ghislain, Kast Robert, Luchini Stéphane, Scapecchi Pascale, 2004, "Valorisation économique des effets de la pollution atmosphérique: Résultats d'une enquête contextuelle”, Revue économique, 55(1), pp. 65-92.

Conesa Héctor M., Schulin Rainer, Nowack Bernd, 2008, "Mining landscape: A cultural tourist opportunity or an environmental problem?: The study case of the Cartagena-La Unión Mining District (SE Spain)”, Ecological Economics, 64(4), pp. 690-700.

De Palma André, PiCard Nathalie, WAddell Paul, 2007, "Discrete choice models with capacity constraints: An empirical analysis of the housing market of the greater Paris region", Journal of Urban Economics, 62(2), pp. 204-230.

Dohmen, T. , Falk, A. , Huffman, D. , Sunde, U. , Schupp, J. and Wagner, G. G. (2011), "Individual risk attitudes: measurement, determinants, and behavioral consequences. Journal of the European Economic Association, 9: 522-550.

Durand Cécile, Sauthier Nicolas, Schwoebel Valérie, 2011, "Évaluation de l'exposition à des sols pollués au plomb, au cadmium et à l'arsenic en Aveyron", Rapport de l'Institut de Veille Sanitaire (InVS), France, CIRE/Production scientifique InVS.

Flanquart Hervé, Hellequin Anne-Peggy, Vallet Pascal, 2013, "Living alongside hazardous factories: risk, choice and necessity", Health, Risk \& Society, 15(8), pp. 663-680.

Geller Andrew, ZeNICK Harold, 2005, “Aging and the Environment: A Research Framework”, Environmental Health Perspectives, 113(9), pp. 1257-1262.

Gramagla Christelle, 2015, "Dwelling in polluted places. How issues about risk are raised, avoided or kept silent in two French towns", in Peilin Li, Roulleau-Berger Laurence (eds.), Ecological Risks and Disasters - New Experiences in China and Europe, 1 edition, Abingdon, Oxon; New York, NY, Routledge.

Guihard-Costa Anne-Marie, Inacio Manuela, Valente Sandra, Ferreira da Silva Eduardo, 2012, "Méthode d'étude spatialisée des effets de la contamination industrielle sur la santé des populations locales, région d'Estarreja (Portugal)", Sud-Ouest européen. Revue géographique des Pyrénées et du Sud-Ouest, 33, pp. 69-76.

Guo Jessica Y., BHAt Chandra R., 2007, “Operationalizing the concept of neighborhood: Application to residential location choice analysis", Journal of Transport Geography, 15(1), pp. 31-45.

Inácio M, Neves O, Pereira V, 2014, "Acumulação de metais pesados em forragens e produtos agrícolas em Podzóis de um local industrial Português”, Comunicações Geológica, 101, pp. 1019-1022.

Jerrett Michael, Burnett Richard T, Kanaroglou Pavlos, Eyles John, Finkelstein Norm, Giovis Chris, Brook Jeffrey R, 2001, "A GIS-Environmental Justice Analysis of Particulate Air Pollution in Hamilton, Canada", Environment and Planning A: Economy and Space, 33(6), pp. 955-973.

LANDRIGAN Philip J., ET AL., “The Lancet Commission on pollution and health”, The Lancet, 391(10119), pp. 462-512.

LAURIAN Lucie, 2008, “Environmental Injustice in France”, Journal of Environmental Planning and Management, 51(1), pp. 55-79. 
LEe Brian H. Y., WAdDELL Paul, 2010, "Residential mobility and location choice: a nested logit model with sampling of alternatives", Transportation, 37(4), pp. 587-601.

MARmot Michael, 2015, “The health gap: the challenge of an unequal world”, The Lancet, 386(10011), pp. 2442-2444.

Miller Jessica Ty, 2016, "Is urban greening for everyone? Social inclusion and exclusion along the Gowanus Canal”, Urban Forestry \& Urban Greening, 19, pp. 285-294.

Mitchell Gordon, WALKer Gordon, 2005, "Methodological issues in the assessment of environmental equity and environmental justice", in Sustainable Urban Development: The environmental assessment methods, Taylor \& Francis, pp. 447-472.

O’Neill Marie S., Jerrett Michael, Kawachi Ichiro, Levy Jonathan I., Cohen Aaron J., Gouveia Nelson, WiLkinson Paul, Fletcher Tony, Cifuentes Luis, Schwartz Joel, Conditions Workshop on Air Pollution and Socioeconomic, 2003, "Health, wealth, and air pollution: advancing theory and methods.”, Environmental Health Perspectives.

Phillimore Peter, Bell Patricia, 2013, “Manufacturing loss: Nostalgia and risk in Ludwigshafen”, Focaal, 2013(67), pp. 107-120.

Schaeffer Y., Cremer-Schulte D., Tartiu C., Tivadar M., 2016, "Natural amenity-driven segregation: Evidence from location choices in French metropolitan areas", Ecological Economics, 130, pp. 37-52.

Schirmer Patrick M., Eggermond Michael A. B. van, Axhausen Kay W., 2014, "The role of location in residential location choice models: a review of literature", Journal of Transport and Land Use, 7(2), pp. 3-21.

Shriver Thomas E., Kennedy Dennis K., 2005, "Contested Environmental Hazards and Community Conflict Over Relocation*”, Rural Sociology, 70(4), pp. 491-513.

TiEBout Charles M., 1956, “A Pure Theory of Local Expenditures”, Journal of Political Economy, 64(5), pp. $416-424$.

VAN DuiJn Mark, Rouwendal Jan, 2013, "Cultural heritage and the location choice of Dutch households in a residential sorting model", Journal of Economic Geography, 13(3), pp. 473-500.

WALTERT Fabian, SchläPFER Felix, 2010, "Landscape amenities and local development: A review of migration, regional economic and hedonic pricing studies", Ecological Economics, 70(2), pp. 141-152.

WooldRIDGE Jeffrey M., 2003, “Cluster-Sample Methods in Applied Econometrics”, American Economic Review, 93(2), pp. 133-138.

Wooldridge Jeffrey M., 2010, Econometric Analysis of Cross Section and Panel Data, Second Edition, Cambridge MA, The MIT Press. 
APPENDIX A: Additional descriptive statistics about study areas

Table A1: Descriptive statistics of study-areas

\begin{tabular}{|c|c|c|c|c|}
\hline & $\begin{array}{l}\text { Portman/ESG } \\
\text { vs. control }\end{array}$ & $\begin{array}{ll}\text { Viviez } & \text { vs. } \\
\text { control } & \\
\end{array}$ & $\begin{array}{l}\text { Alumbres } \\
\text { vs. control }\end{array}$ & $\begin{array}{l}\text { Estarreja } \\
\text { vs. control } \\
\end{array}$ \\
\hline \multicolumn{5}{|l|}{ Attachment to the area } \\
\hline Ratio of area lifetime/age $(\%)$ & $0.11 * *$ & $0.08 *$ & $0.30 * * *$ & $0,08 * * *$ \\
\hline Intention to move out in the next 5 years (proportion) & 0,01 & $0.13 * * *$ & $0.10^{*}$ & 0,01 \\
\hline Living here for economic reasons (proportion) & $0.19^{* * *}$ & $0.12 * *$ & $-0.10^{*}$ & $-0,02$ \\
\hline Living here for professional reasons (proportion) & $0.31 * * *$ & $-0.10 *$ & $0.12^{* *}$ & $0,20 * * *$ \\
\hline Living here for social/family reasons (proportion) & $0.10^{*}$ & $-0,01$ & $0.15^{* *}$ & 0,01 \\
\hline Living here for environmental reasons (proportion) & $-0.24 * * *$ & $-0.28 * * *$ & $-0.08 * *$ & $-0,09 * * *$ \\
\hline Living here for public facilities (proportion) & $0.04 *$ & $-0.07 * *$ & 0,02 & $-0,02$ \\
\hline
\end{tabular}

Source: Authors' calculation from the CSPE database.

Figure A1 shows that "social ties" play an important role on residential motivations for all study-areas; as they are more often mentioned than "professional reasons" and "economic reasons". Nonetheless, referring to Table A1, "professional reasons" are particularly mentioned as a motivation for living in Alumbres and Estarreja. Table A1 also shows that residents more often mention to have chosen to live in Viviez and Portman/ESG for "interesting economic reasons" (e.g. affordable housing price) compared to residents from non-polluted areas, who more often mention "environmental amenities" as residential motivation. This result is not surprising given the presence of an active industry supplying various jobs in both areas. Furthermore, strong community attachment and satisfaction are characteristics that are highlighted in several active industrial sites in Europe. However, perceived area attractiveness is significantly lower in these active sites (Viviez and Alumbres), compared to their respective control groups. This might be due to the presence of smokes, smells and noises.

Table A1 also shows stronger intentions to move out for residents from Viviez and Alumbres compared to their respective control groups. In these two municipalities, “environmental issues" appear as the most mentioned motivation for moving out (Figure A2). In contrast, “environmental issues" does not appear as a specific move-out issue in Portman/ESG and Estarreja, compared to their respective counterparts. On the other hand, area attractiveness perceptions in Portman/ESG and Estarreja do not differ from their respective control areas. This absence of significant gap is not so surprising since, in both areas, there are close environmental amenities that residents can enjoy despite the presence of pollution (e.g. lagoon, sea, or ocean). In addition, pollution is not directly visible in Portman/ESG (i.e. mines closed since 1990) and can be relatively far in Estarreja for people living in other freguesias than Beduido \& Veiros (where the chemical complex is located). In the same way, Table 1 does not show significant differences regarding move-out intentions in Portman/ESG and Estarreja, compared to their respective control group. 
Figure A1: Main mentioned reason for living in the area

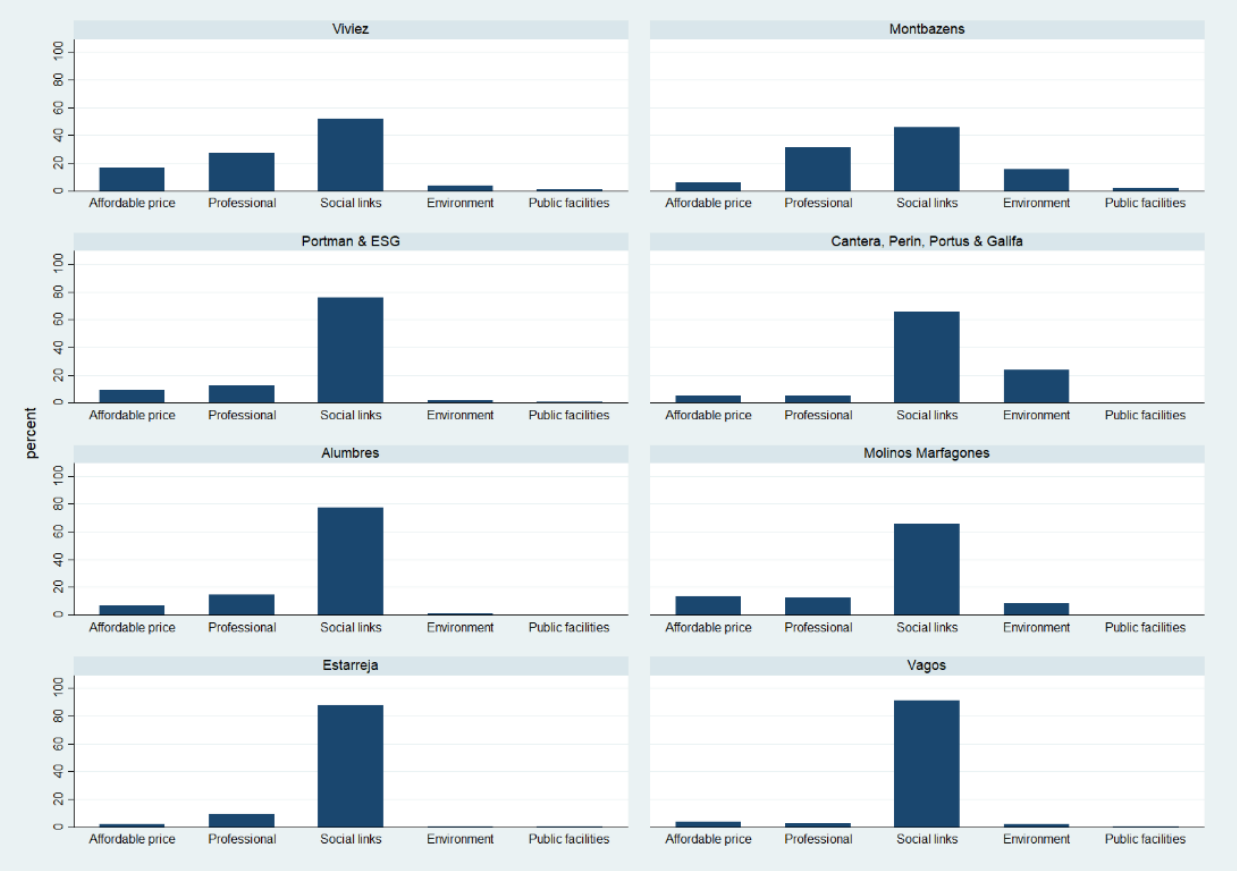

Source: CSPE database, authors' computation.

Figure A2: Main mentioned reason for move-out intentions in the next 5 years
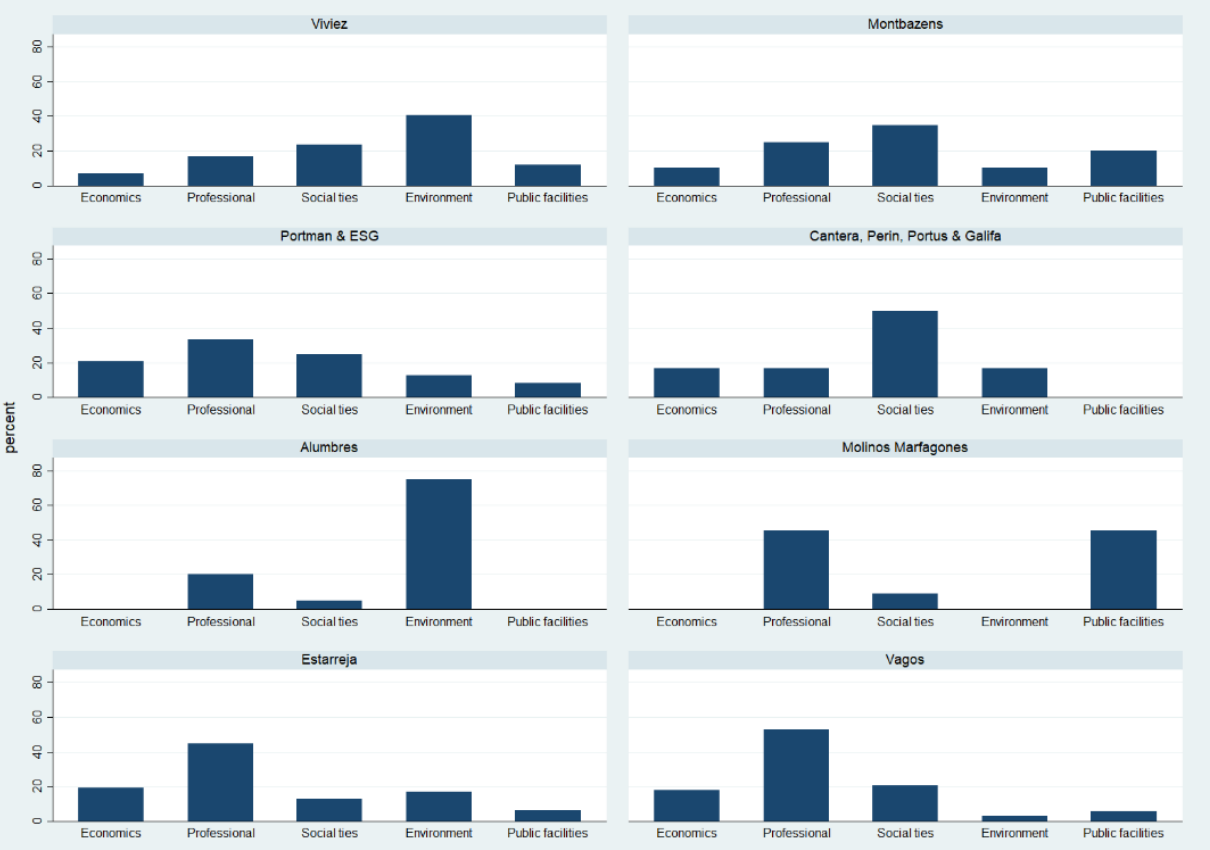

Vagos

Source: CSPE database, authors' computation. 


\section{APPENDIX B: Additional materials}

Table B1: Description of variables used in Eq.1 and Eq.3

\begin{tabular}{|c|c|}
\hline Variable name & Description \\
\hline Living in polluted areas (dummy) & $\begin{array}{l}\text { Takes the value } 1 \text { if the household lives in a polluted area (Viviez, Sierra Minera, } \\
\text { Estarreja) and } 0 \text { if it lives in a control area (Montbazens, Catargena West, Vagos). }\end{array}$ \\
\hline Intention to move out in the next five years & $\begin{array}{l}\text { Takes the value } 1 \text { if the household plans to move out of the community in the next } \\
\text { five years, } 0 \text { otherwise. }\end{array}$ \\
\hline Number of children (lower than 17yo) & Quantity of children in the household. \\
\hline Number of young adults (18-29yo) & Quantity of young adults in the household. \\
\hline Number of lower-middle age adults (30-44yo) & Quantity of lower-middle age adults in the household. \\
\hline Number of higher middle age adults (45-64yo) & Quantity of higher-middle age adults in the household. \\
\hline Number of old adults (higher than 65yo) & Quantity of old adults in the household. \\
\hline Number of male members & Quantity of male members in the household. \\
\hline Respondent is in a couple (dummy) & Takes the value 1 if the respondent is in a couple (married or free union), 0 otherwise. \\
\hline Respondent is single (dummy) & Takes the value 1 if the respondent is single, 0 otherwise. \\
\hline Number of members with foreign parents & Quantity of adult members with foreign parents in the household. \\
\hline Number of rooms & Number of rooms in the housing. \\
\hline Having a garden (dummy) & Takes the value 1 if the housing has a private garden, 0 otherwise. \\
\hline Presence of family members around (dummy) & $\begin{array}{l}\text { Takes the value } 1 \text { if there are family members living in the same community, } 0 \\
\text { otherwise. }\end{array}$ \\
\hline Lifetime in the area (in year) & Duration of residence in the community in years. \\
\hline $\begin{array}{l}\text { Willingness to live in a polluted land that decreases life expectancy } \\
\text { by } 5 \text { yo (1-to-5 scale) }\end{array}$ & $\begin{array}{l}\text { The scale varies from } 1 \text { "a very low willingness to live in a place that may reduce life } \\
\text { expectancy by } 5 \text { yo" to } 5 \text { "a very high willingness to take this risk". }\end{array}$ \\
\hline Number of members who obtained a high-school grade & Number of household members who obtained a high-school diploma \\
\hline Wealth index (0-to-7 score) & $\begin{array}{l}\text { Wealth index is the sum of the following owned (or not) assets: former house, second } \\
\text { house, car, air conditioner, computer, cellphone and financial assets. Thus, the } \\
\text { wealthiest households have a score of } 7 \text { while the most deprived household a score of } \\
0 \text {. }\end{array}$ \\
\hline $\ln ($ monthly total household income) & $\begin{array}{l}\text { Before being log-transformed, monthly total household incomes are corrected using } \\
\text { purchasing power parities (PPP) based on } 2017 \text { US dollars: } 0.581 \text { for Portugal, } 0.641 \\
\text { for Spain and } 0.776 \text { for France. }\end{array}$ \\
\hline Respondent's height & Height of the respondent in meters \\
\hline Respondent's parental education & $\begin{array}{l}\text { Takes the value } 1 \text { if at least one parent of the respondent obtained a high-school } \\
\text { diploma, } 0 \text { otherwise. }\end{array}$ \\
\hline
\end{tabular}

Source: Authors' computation from the CSPE database. 
Table B2: Factors correlated to the probability of living in polluted areas, average marginal effects

\begin{tabular}{|c|c|c|c|c|}
\hline & (1) & (2) & (3) & (4) \\
\hline Number of children (lower than 17yo) & $\begin{array}{l}-0.006 \\
(-0.19)\end{array}$ & $\begin{array}{l}-0.021 \\
(-0.75)\end{array}$ & $\begin{array}{l}-0.007 \\
(-0.26)\end{array}$ & $\begin{array}{l}-0.020 \\
(-0.75)\end{array}$ \\
\hline Number of young adults (18-29yo) & $\begin{array}{l}0.065^{*} \\
(1.86)\end{array}$ & $\begin{array}{l}0.054 \\
(1.37)\end{array}$ & $\begin{array}{l}0.070 * * \\
(1.97)\end{array}$ & $\begin{array}{l}0.055 \\
(1.48)\end{array}$ \\
\hline Number of lower-middle age adults (30-44yo) & $\begin{array}{l}0.029 \\
(0.79)\end{array}$ & $\begin{array}{l}0.030 \\
(0.60)\end{array}$ & $\begin{array}{l}0.039 \\
(1.02)\end{array}$ & $\begin{array}{l}0.038 \\
(0.80)\end{array}$ \\
\hline Number of higher middle age adults (45-64yo) & $\begin{array}{l}-0.024 \\
(-0.85)\end{array}$ & $\begin{array}{l}-0.041 \\
(-0.89)\end{array}$ & $\begin{array}{l}-0.021 \\
(-0.81)\end{array}$ & $\begin{array}{l}-0.039 \\
(-0.92)\end{array}$ \\
\hline Number of old adults (higher than 65yo) & $\begin{array}{l}-0.061 * * \\
(-2.01)\end{array}$ & $\begin{array}{l}-0.094 * * \\
(-2.03)\end{array}$ & $\begin{array}{l}-0.051^{*} \\
(-1.67)\end{array}$ & $\begin{array}{l}-0.095^{* *} \\
(-2.11)\end{array}$ \\
\hline Number of male members & $\begin{array}{l}-0.028 \\
(-1.04)\end{array}$ & $\begin{array}{l}-0.008 \\
(-0.23)\end{array}$ & $\begin{array}{l}-0.031 \\
(-1.12)\end{array}$ & $\begin{array}{l}-0.012 \\
(-0.35)\end{array}$ \\
\hline Respondent is in a couple (dummy) & $\begin{array}{l}0.040 \\
(1.53)\end{array}$ & $\begin{array}{l}0.087 * * \\
(2.57)\end{array}$ & $\begin{array}{l}0.054 * * \\
(2.16)\end{array}$ & $\begin{array}{l}0.107 * * * \\
(2.91)\end{array}$ \\
\hline Respondent is single (dummy) & $\begin{array}{l}0.072 \\
(1.38)\end{array}$ & $\begin{array}{l}0.127 * * \\
(2.36)\end{array}$ & $\begin{array}{l}0.071 \\
(1.40)\end{array}$ & $\begin{array}{l}0.107 * \\
(1.93)\end{array}$ \\
\hline Number of members with foreign parents & $\begin{array}{l}0.093 * * * \\
(3.53)\end{array}$ & $\begin{array}{l}0.085 * * * \\
(2.94)\end{array}$ & $\begin{array}{l}0.091 * * * \\
(3.58)\end{array}$ & $\begin{array}{l}0.082 * * * \\
(2.82)\end{array}$ \\
\hline Number of rooms & $\begin{array}{l}0.055^{* * * *} \\
(3.94)\end{array}$ & $\begin{array}{l}0.056 * * * \\
(3.60)\end{array}$ & $\begin{array}{l}\mathbf{0 . 0 8 6 * * *} \\
(3.87)\end{array}$ & $\begin{array}{l}\mathbf{0 . 1 2 9} * * * \\
(3.60)\end{array}$ \\
\hline Having a garden (dummy) & $\begin{array}{l}-0.181 * * * \\
(-2.96)\end{array}$ & $\begin{array}{l}-0.165 * * \\
(-2.46)\end{array}$ & $\begin{array}{l}-0.186 \text { *** } \\
(-2.95)\end{array}$ & $\begin{array}{l}-0.156^{* *} \\
(-2.25)\end{array}$ \\
\hline Presence of family members around (dummy) & $\begin{array}{l}0.154 * * \\
(2.04)\end{array}$ & $\begin{array}{l}0.176^{* * * *} \\
(2.58)\end{array}$ & $\begin{array}{l}0.156^{* *} \\
(2.11)\end{array}$ & $\begin{array}{l}0.187 * * * \\
(2.61)\end{array}$ \\
\hline Lifetime in the area (in year) & $\begin{array}{l}0.004 * * * \\
(5.17)\end{array}$ & $\begin{array}{l}0.005 * * * \\
(5.52)\end{array}$ & $\begin{array}{l}0.004 * * * \\
(5.23)\end{array}$ & $\begin{array}{l}0.004 * * * \\
(5.19)\end{array}$ \\
\hline $\begin{array}{l}\text { Willingness to live in a polluted land that decreases life expectancy by } 5 \text { yo } \\
\text { (1-to-5 scale) }\end{array}$ & $\begin{array}{l}0.101^{* * *} \\
(2.36)\end{array}$ & $\begin{array}{l}0.096^{* * *} \\
(2.22)\end{array}$ & $\begin{array}{l}0.103^{* * *} \\
(2.40)\end{array}$ & $\begin{array}{l}0.099 * * \\
(2.32)\end{array}$ \\
\hline Number of members who obtained a high school grade & $\begin{array}{l}-0.076 * * * * \\
(-2.58)\end{array}$ & $\begin{array}{l}-0.061 * \\
(-1.82)\end{array}$ & $\begin{array}{l}-0.086 * * * \\
(-3.02)\end{array}$ & $\begin{array}{l}-0.063^{*} \\
(-1.87)\end{array}$ \\
\hline Wealth index (0-to-7 score) & $\begin{array}{l}0.125 * * * \\
(3.45)\end{array}$ & & & \\
\hline Square of wealth index & $\begin{array}{l}-0.017 * * * \\
(-2.83)\end{array}$ & & & \\
\hline $\ln ($ monthly total household income) & & $\begin{array}{l}1.140 * * \\
(2.08)\end{array}$ & & \\
\hline Square of $\ln$ (income) & & $\begin{array}{l}-0.075 * * \\
(-2.05)\end{array}$ & & \\
\hline Wealth - Tercile 1 & & & $\begin{array}{l}0.342 \text { *** } \\
(2.66)\end{array}$ & \\
\hline Wealth - Tercile 2 & & & $\begin{array}{l}0.252^{* * *} \\
(2.24)\end{array}$ & \\
\hline RoomNumber*WealthT1 & & & $\begin{array}{l}-0.055 * * \\
(-2.49)\end{array}$ & \\
\hline RoomNumber*WealthT2 & & & $\begin{array}{l}-0.016 \\
(-0.88)\end{array}$ & \\
\hline Income - Quintile 1 & & & & $\begin{array}{l}0.618 * * * \\
(3.54)\end{array}$ \\
\hline Income - Quintile 2 & & & & $\begin{array}{l}0.462 * * \\
(2.47)\end{array}$ \\
\hline Income - Quintile 3 & & & & $\begin{array}{l}0.363^{* * *} \\
(2.19)\end{array}$ \\
\hline Income - Quintile 4 & & & & $\begin{array}{l}0.306 \\
(1.44)\end{array}$ \\
\hline RoomNumber*IncomeQ1 & & & & $\begin{array}{l}-0.130 * * * \\
(-3.50)\end{array}$ \\
\hline RoomNumber*IncomeQ2 & & & & $\begin{array}{l}-0.084 * * \\
(-2.31)\end{array}$ \\
\hline RoomNumber*IncomeQ3 & & & & $\begin{array}{l}-0.054 * \\
(-1.69)\end{array}$ \\
\hline RoomNumber*IncomeQ4 & & & & $\begin{array}{l}-0.052 \\
(-1.39)\end{array}$ \\
\hline Country fixed effects & Yes & Yes & Yes & Yes \\
\hline Observations & 1,144 & 939 & 1,144 & 939 \\
\hline Pseudo R-square & 0.119 & 0.126 & 0.127 & 0.137 \\
\hline Observed probability & 0.576 & 0.573 & 0.576 & 0.573 \\
\hline Predicted probability & 0.586 & 0.583 & 0.588 & 0.585 \\
\hline
\end{tabular}

Notes: (1) Standard errors are robust to intra-group correlation. Significance levels are: $* * * 1 \%$, **5\%, *10\%,

(2) Wealth index is the sum of the following owned (or not) assets: former house, second house, car, air conditioner, computer, cellphone and financial assets. Thus, the wealthiest households have a score of 7 while the most deprived household a score of 0 .

(3) Before being log-transformed, household incomes are corrected using purchasing power parities (PPP) based on 2017 US dollars: 0.581 for Portugal, 0.641 for Spain and 0.776 for France.

(4) Potential endogenous regressors are in bold between sidebars.

Source: Authors' calculation from the CSPE database. 
Table B2 lists average marginal effects at the mean point. Household socioeconomic factors are strong predictors of residential location. For example, column 1 shows a U-inverted relationship between wealth index and the probability of living in polluted areas (the turning point being around 3-4 owned assets). In the same way, Column 2 indicates a similar Uinverted relationship when logged household income (adjusted in \$PPP) is used instead of wealth index (the turning point being around 1918 \$PPP, i.e. 1,113 euros in Portugal, 1,230 euros in Spain, and 1,489 euros in France). Households with lower-middle wealth and income have the highest probability of living in polluted areas, in line with results in Figure 3 . $^{7}$ Interestingly, housing size is a significant predictor of the probability of living in polluted areas, especially for young families with moderate wealth and incomes. For households belonging to the first wealth tercile, an extra room per housing unit increases the probability of living in polluted areas by 3.2 percentage points (Column 3$).{ }^{8}$ Using interaction terms (Column 4), we find that, for households belonging to the first, second and third income quintiles, an extra room increases this probability by $0.3,4.3$ and 7.4 percentage points, respectively. It is worth noting that, even if households with lower socioeconomic status can live in larger houses at affordable price in polluted areas, they are significantly less likely to enjoy having a private garden (a reduction of around 17-19 percentage points), perhaps because of heavy contamination of the soil.

Apart from socioeconomic patterns, other factors may explain why individuals live in polluted areas. For instance, community attachment seems to increase the risk of living near polluted sites. Indeed, the presence of a family network increases the risk by 15-18 percentage points, while 10 extra years of living in the area increases it by 4-5 percentage points. Moreover, for all model specifications, families of foreign origin and households with a low level of education have higher risks of living in polluted areas. For instance, in Column 1, one extra member with parents of foreign origin increases the probability of living in a polluted area by nine percentage points.

Demographic factors also produce interesting results. In terms of marital status, single individuals and couples have a higher probability of living in polluted areas compared to individuals who have suffered from marital upheavals (divorce, separation or widowhood), except in Column 1 when wealth is controlled for (i.e. potential collinearity between wealth and marital status). The proportion of old adults in the household reduces the probability of living in polluted areas. This underrepresentation of the elderly in polluted areas is consistent with the literature showing that the retirees are significantly attracted by environmental factors (van Duijn and Rouwendal, 2013). Moreover, frail elderly people tend to be more threatened by mortality risks due to daily pollution exposure than younger individuals (Geller and Zenick, 2005).

Finally, as expected, environmental health risk aversion is negatively correlated with the probability of living in polluted areas. In other words, people who live near mining- and industrial wastes tend to be more risk-takers concerning the health effects of daily exposure to pollution. ${ }^{9}$

Table B3: First-step estimates in IV model, linear regression of household socioeconomic status on instruments and control variables

\begin{tabular}{|c|c|c|c|c|c|c|}
\hline & $\begin{array}{l}\text { Number of } \\
\text { educated } \\
\text { members }\end{array}$ & $\begin{array}{l}\text { Number of } \\
\text { educated } \\
\text { members }\end{array}$ & $\begin{array}{l}\text { Wealth } \\
\text { index }\end{array}$ & $\begin{array}{l}\text { Wealth } \\
\text { index }\end{array}$ & $\ln ($ income) & $\ln ($ income $)$ \\
\hline Height of the respondent (in meters) & $1.252 * * *$ & $1.157 * * *$ & $1.611 * * *$ & $1.490 * * *$ & $0.943 * * *$ & $0.866 * * *$ \\
\hline
\end{tabular}

\footnotetext{
${ }^{7}$ We regress wealth index and household incomes in independent specifications to avoid multi-collinearity problems.

${ }^{8}$ An alternative model specification adding interaction terms between age groups proportions and housing size shows that housing size particularly increases the probability of living in polluted areas for the 30-45 age group (not shown).
} 


\begin{tabular}{|c|c|c|c|c|c|c|}
\hline $\begin{array}{l}\text { Parental education of the respondent (at least a high- } \\
\text { school diploma) }\end{array}$ & $(4.09)$ & $\begin{array}{l}(3.64) \\
0.433 * * * \\
(\mathbf{5 . 1 3})\end{array}$ & $(3.57)$ & $\begin{array}{l}(3.30) \\
0.333 * * * \\
(3.11) \\
\end{array}$ & (4.54) & $\begin{array}{l}(4.15) \\
0.266 * * * \\
(5.21)\end{array}$ \\
\hline \multirow[t]{2}{*}{ Number of children (lower than 17yo) } & 0.006 & -0.011 & 0.055 & 0.029 & 0.036 & 0.027 \\
\hline & $(0.07)$ & $(-0.15)$ & $(1.10)$ & $(0.57)$ & $(0.90)$ & $(0.61)$ \\
\hline \multirow[t]{2}{*}{ Number of young adults (18-29yo) } & $0.607 * * *$ & $0.538 * * *$ & $0.248 * * *$ & $0.193 * * *$ & $0.267 * * *$ & $0.228 * * *$ \\
\hline & $(9.86)$ & $(7.58)$ & $(3.74)$ & $(3.09)$ & $(5.50)$ & $(4.58)$ \\
\hline \multirow[t]{2}{*}{ Number of lower-middle age adults (30-44yo) } & $0.498 * * *$ & $0.440 * * *$ & $0.349 * * *$ & $0.310 * * *$ & $0.367 * * *$ & $0.350 * * *$ \\
\hline & $(7.14)$ & $(7.88)$ & $(4.33)$ & $(3.72)$ & $(10.29)$ & $(9.59)$ \\
\hline \multirow[t]{2}{*}{ Number of higher middle age adults (45-64yo) } & $0.351 * * *$ & $0.343 * * *$ & $0.373 * * *$ & $0.365 * * *$ & $0.268 * * *$ & $0.275 * * *$ \\
\hline & $(7.50)$ & $(9.30)$ & $(4.94)$ & $(4.47)$ & $(7.97)$ & $(8.33)$ \\
\hline \multirow[t]{2}{*}{ Number of old adults (higher than 65yo) } & $0.131 * *$ & $0.126 * *$ & -0.044 & -0.041 & $0.149 * * *$ & $0.170 * * *$ \\
\hline & $(2.13)$ & $(2.36)$ & $(-0.42)$ & $(-0.41)$ & $(4.83)$ & $(5.21)$ \\
\hline \multirow[t]{2}{*}{ Number of male members } & -0.082 & -0.061 & -0.028 & -0.017 & -0.040 & -0.031 \\
\hline & $(-1.50)$ & $(-0.99)$ & $(-0.47)$ & $(-0.24)$ & $(-1.49)$ & $(-1.04)$ \\
\hline \multirow[t]{2}{*}{ Respondent is in a couple (dummy) } & 0.070 & 0.042 & $0.696^{* * * *}$ & $0.717 * * *$ & $0.252 * * *$ & $0.237 * * *$ \\
\hline & $(0.86)$ & $(0.53)$ & (7.67) & (7.89) & $(6.79)$ & $(7.78)$ \\
\hline \multirow[t]{2}{*}{ Respondent is single (dummy) } & -0.076 & -0.163 & $0.324 * * *$ & $0.346^{* * *}$ & 0.089 & 0.059 \\
\hline & $(-0.75)$ & $(-1.50)$ & $(3.05)$ & $(3.19)$ & $(1.23)$ & $(1.00)$ \\
\hline \multirow[t]{2}{*}{ Number of rooms } & $0.052 * * *$ & $0.047 * * *$ & $0.220 * * *$ & $0.235 * * *$ & $0.076^{* * *}$ & $0.071 * * *$ \\
\hline & $(3.81)$ & $(3.18)$ & $(7.83)$ & $(9.60)$ & $(5.64)$ & $(5.19)$ \\
\hline \multirow[t]{2}{*}{ Constant } & $-2.536 * * *$ & $-2.347 * * *$ & -0.787 & -0.703 & $4.961 * * *$ & $5.085 * * *$ \\
\hline & $(-5.19)$ & $(-4.45)$ & $(-1.03)$ & $(-0.91)$ & $(13.73)$ & $(13.71)$ \\
\hline Country fixed effects & Yes & Yes & Yes & Yes & Yes & Yes \\
\hline Observations & 1,147 & 1,098 & 1,147 & 1,098 & 943 & 911 \\
\hline R-square & 0.302 & 0.329 & 0.340 & 0.353 & 0.436 & 0.464 \\
\hline
\end{tabular}

Notes: (1) Standard errors are robust to intra-group correlation. Significance levels are: ***1\%, **5\%, *10\%,

(2) Wealth index is the sum of the following owned (or not) assets: former house, second house, car, air conditioner, computer, cellphone and financial assets. Thus, the wealthiest households have a score of 7 while the most deprived household a score of 0 . Incomes are in US\$ PPA.

Source: Authors' calculation from the CSPE database. 
Table B4: Reduced-form regression of the dependent variable on the instruments, marginal effects

\begin{tabular}{|c|c|}
\hline & Prob(LivingPollutedAreas) \\
\hline Height of the respondent (in meters) & $-0.548 * * *$ \\
\hline Parental education of the respondent (at least a high-school level) & $\begin{array}{l}-0.075 * \\
(-1.80)\end{array}$ \\
\hline Number of children (lower than 17yo) & $\begin{array}{l}-0.003 \\
(-0.10)\end{array}$ \\
\hline Number of young adults (18-29yo) & $\begin{array}{l}0.019 \\
(0.56)\end{array}$ \\
\hline Number of lower-middle age adults (30-44yo) & $\begin{array}{l}-0.003 \\
(-0.07)\end{array}$ \\
\hline Number of higher middle age adults (45-64yo) & $\begin{array}{l}-0.061 * \\
(-1.84)\end{array}$ \\
\hline Number of old adults (higher than 65yo) & $\begin{array}{l}-0.037 \\
(-1.04)\end{array}$ \\
\hline Number of male members & $\begin{array}{l}-0.018 \\
(-0.59)\end{array}$ \\
\hline Respondent is in a couple (dummy) & $\begin{array}{l}0.049 \\
(1.08)\end{array}$ \\
\hline Respondent is single (dummy) & $\begin{array}{l}0.085 \\
(1.64)\end{array}$ \\
\hline Number of rooms & $\begin{array}{l}0.045^{* * * *} \\
(4.51)\end{array}$ \\
\hline Country fixed effects & Yes \\
\hline Observations & 1,098 \\
\hline R-square & 0.0295 \\
\hline
\end{tabular}

Source: Authors' calculation from the CSPE database. 
Table B5: Factors of interest NOT correlated to the intention to move out of polluted areas in the next 5 years, average marginal effects based on Eq.2

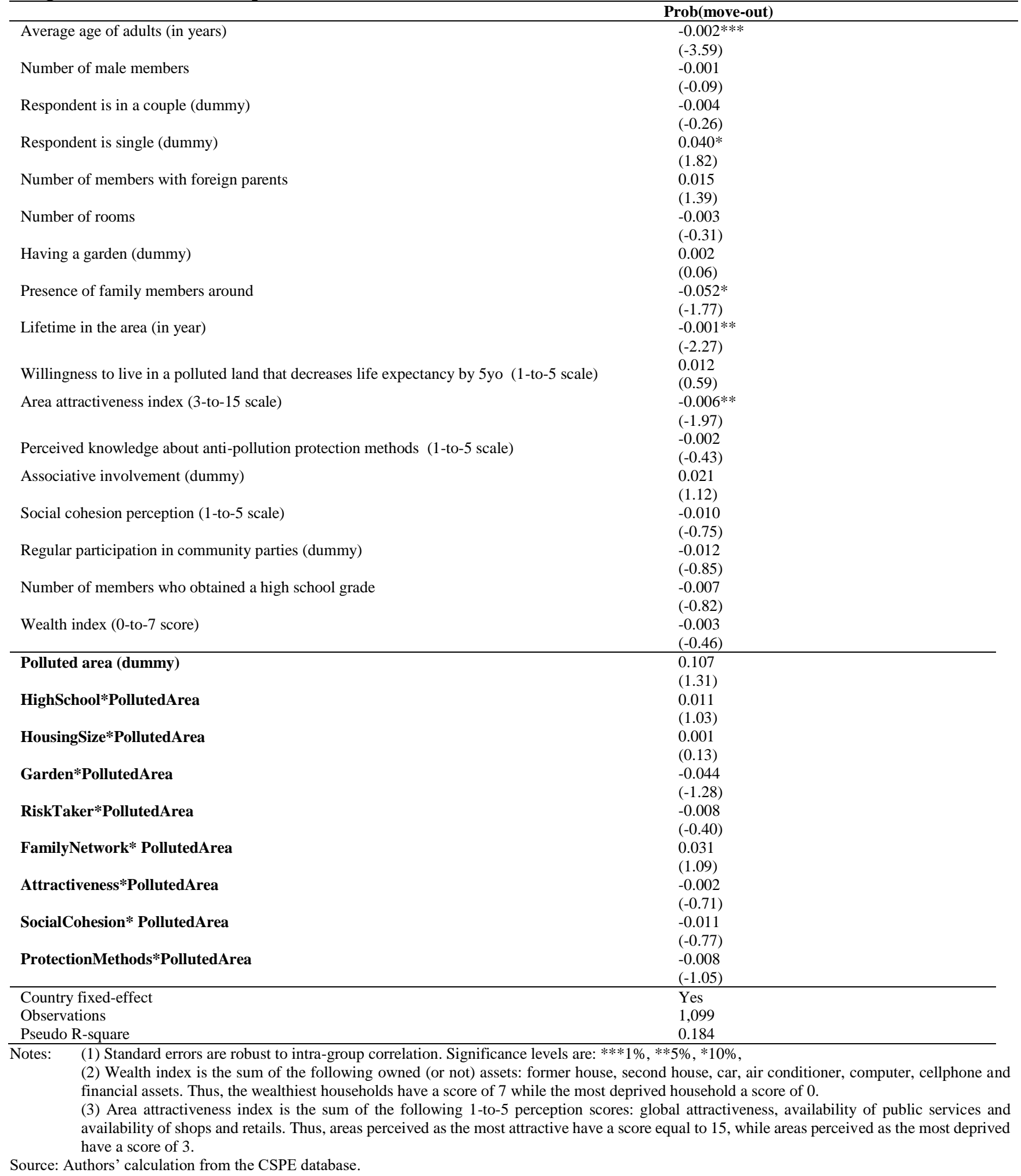




\section{CEE-M Working Papers' - 2019}

WP 2019 - 01

WP $2019-02$

WP 2019 - 03

WP $2019-04$

WP $2019-05$

WP 2019 - 06

WP $2019-07$

WP $2019-08$

WP $2019-09$

WP 2019 - 10

WP $2019-11$

WP $2019-12$
Adrien Nguyen-Huu. \& Antonin Pottier «Hicksian Traverse Revisited: Conditions for the Energy Transition»

Oumar Mbodji, Adrien Nguyen-Huu \& Traian A. Pirvu «Optimal Sharing Rule for a Household with a Portfolio Management Problem»

Tristan Cotty, Tristan, Elodie Maitre d'Hotel \&Julie Subervie «Inventory credit to enhance food security in Africa»

Raphael Soubeyran

«Incentives, Pro-social Preferences and Discrimination»

Adrien Fabre, Mouez Fodhaz \& Francesco Ricci «Optimal Timing of Energy Production»

Claude Bismut \& Ismaël Rmajo

«A world of low interest rates»

Gabriela Demarchi, Julie Subervie, Fernando Palha Leite $\&$ Jean-Paul Laclau

« Farmers' preferences for water-saving strategies in brazilian eucalypt plantation »

Arnaud Tognetti, David Doat, Dimitri Dubois \& Rustam Romaniuc "Does the presence of a physically disabled erson in the group increase cooperation? An experimental test of the empathyaltruism hypothesis »

Isabelle Tritsch, Gwenole Le Velly, Benoit Mertens, Patrick, Meyfroidt, Christophe Sannier, Jean-Sylvestre Makak \& Kenneth Houngbedji «Do Forest-Management Plans and FSC Certification Reduce deforestation in the Congo Basin? »

Jean-Michel Salles

"Valuing the loss and damage from climate change: a review of some current issues »

Can Askan Mavi

«Can harmful events be another source of environmental traps? »

Daniel Serra

« Neuroeconomics and Modern Neuroscience »

${ }^{1}$ CEE-M Working Papers / Contact : laurent.garnier@inra.fr

- RePEc https://ideas.repec.org/s/hal/wpceem.html

- HAL https://halshs.archives-ouvertes.fr/CEE-M-WP/ 
WP $2019-13$

WP $2019-14$

WP $2019-15$

WP $2019-16$

\section{Daniel Serra}

«La neuroeconomie en question : debats et controversies»

Claire Richert, Katrin Erdlenbruch \& Frédéric Grelot

« The impact of flood management policies individual adaptation actions:

insights from a French case study »

Margaux Lapierre, Alexandre Sauquet \& Julie Subervie

« Improving Farm Environmental Performance through Technical Assistance:

Empirical Evidence on Pesticide Use»

Pierre Levasseur, Katrin Erdlenbruch \& Christelle Gramaglia «Why do people continue to live near polluted sites? Empirical evidence from Southwestern Europe 